Utah State University

DigitalCommons@USU

$1-31-2019$

\title{
Back to the Future: Conserving Functional and Phylogenetic Diversity in the Amphibian-Climate Refuges
}

\author{
Ricardo Lourenço-de-Moraes \\ Universidade Estadual de Maringá \\ Felipe S. Campos \\ Universitat de Barcelona \\ Rodrigo B. Ferreira \\ Universidade Vila Velha \\ Mirco Solé \\ Universidade Estadual de Santa Cruz \\ Karen H. Beard \\ Utah State University \\ Rogério P. Bastos \\ Universidade Estadual de Maringá \\ Follow this and additional works at: https://digitalcommons.usu.edu/eco_pubs \\ Part of the Other Life Sciences Commons
}

\section{Recommended Citation \\ Lourenço-de-Moraes, R., Campos, F.S., Ferreira, R.B. et al. Biodivers Conserv (2019) 28: 1049. \\ https://doi.org/10.1007/s10531-019-01706-x}

This Article is brought to you for free and open access by the Ecology Center at DigitalCommons@USU. It has been accepted for inclusion in Ecology Center Publications by an authorized administrator of DigitalCommons@USU.

For more information, please contact

digitalcommons@usu.edu.

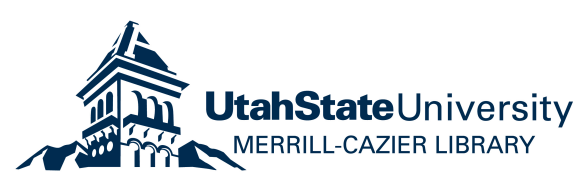


1 Back to the future: Conserving functional and phylogenetic diversity in the amphibian-climate refuges.

3 Ricardo Lourenço-de-Moraes ${ }^{1,2 *}$, Felipe S. Campos ${ }^{3}$, Rodrigo B. Ferreira ${ }^{4}$, Mirco Solé ${ }^{5}$, Karen H. Beard ${ }^{6}$, 4 Rogério P. Bastos ${ }^{1}$

5

6 7

8

9

${ }^{1}$ Programa de Pós-graduação em Ecologia de Ambientes Aquáticos Continentais (PEA), Universidade Estadual de Maringá, Maringá, PR, Brazil

${ }^{2}$ Laboratório de Herpetologia e Comportamento Animal, Universidade Federal de Goiás, Campus Samambaia, 74001-970, Goiânia, GO, Brazil

${ }^{3}$ Departament de Biologia Evolutiva, Ecologia i Ciències Ambientals, Facultat de Biologia, Universitat de Barcelona, ES-08028, Barcelona, Spain

${ }^{4}$ Programa de Pós-graduação em Ecologia de Ecossistemas, Universidade Vila Velha, 29102-920, Vila Velha, ES, Brazil

${ }^{5}$ Departamento de Ciências Biológicas, Universidade Estadual de Santa Cruz, 45662-000, Ilhéus, BA, Brazil

${ }^{6}$ Department of Wildland Resources and the Ecology Center, Utah State University, 84322-5230, Logan, UT, USA

*Correspondence: Ricardo Lourenço-de-Moraes; Programa de Pós-graduação em Ecologia de Ambientes Aquáticos Continentais, Universidade Estadual de Maringá, Paraná, Brazil. Email:

ricardo_lmoraes@hotmail.com; Phone: (+55)4432381821; Fax: (+55)4432381821

ORCID: 0000-0001-6055-5380

Abstract Climate refuges have been used by several species over historical climate change. Ectothermic species often display good models for climate change studies because they are highly sensitive to temperature. Analysis of species loss with ecosystem and evolutionary values helps to understand environmental processes and climate consequences. Here, we associate the functional and phylogenetic diversity of amphibians in the Atlantic Forest hotspot, using multiple models for the present and future conditions. Through a novel approach, we predict species' threat status by 2080 , following the IUCN's criterion B1. Our results estimate a drastic reduction in species richness, ecosystem functioning and evolutionary history at low latitudes and altitudes. We show that species will tend to disperse to the areas with milder temperatures (i.e., high latitudes/altitudes). Some of these areas are the same climate refuges that have been suggested for the Late Pleistocene. We highlight that $60 \%$ of 
31 amphibians can become threatened under future conditions. This work advances the knowledge on climate

32 refuges for amphibian ecology and evolution, supporting complementary tools for conservation strategies.

33

34 Keywords: Anthropocene, Climate change, Atlantic Forest, Anura, Gymnophiona

35

36 Acknowledgements

37 We thank Thiago F. Rangel for providing access computational to the platform Bioensembles. We are grateful to

38 the Asociación Española de Ecología Terrestre (AEET) for the research award granted to conduct this research.

39 We thank the Institut de Biologia Evolutiva (CSIC-UPF) for making the use of lab computers available. We

40 thank the CNPq (140710/2013-2; 152303/2016-2) and the CAPES Foundation (99999.001180/2013-04) for the

41 financial support in this work. We also thank the Technical and Scientific Committee of the Forest Institute of

42 São Paulo (COTEC), Environmental Institute of Paraná (IAP), and the Chico Mendes Institute for the logistical

43 support and the collection licenses (ICMBio/SISBIO:30344; 44755). 


\section{Introduction}

Over millions of years, the Earth has undergone several climatic transformations that seem to appear to be cyclical (Raup and Sepkoski 1982). During these changes, most species had to take refuge in areas with milder environments and better resource availability (Haffer 1969; Mayr and O’Hara 1986; Bush 1994; Bush and Oliveira 2006; Carnaval et al. 2009; Bush et al. 2011). However, these cyclical events lead to five massive extinctions (Raup and Sepkoski 1982; Jablouski 1994; Bambach 2006; Barnorsky et al. 2011).

The current Anthropocene Age is directing toward the sixth mass extinction of the biodiversity (Wake and Vredenburg 2008; Barnosky et al. 2011; Dirzo et al. 2014).

Anticipating climate consequences on biogeographic patterns are key to address changes on functional and phylogenetic diversity relations to organism-mediated ecosystem goods and services (Montoya and Raffaelli 2010; Cardinale et al. 2011; Prather et al. 2012), as well as evolutionary processes (Thuiller et al. 2011; Pio et al. 2014). In this context, studies available about climate change should be evaluated integrating functional and phylogenetic diversity (Sobral and Ciacianruso 2012; Campos et al. 2017). Functional diversity is the value and variation of species and their characteristics that influence the functioning of communities (Tilman 2001) and the phylogenetic diversity is a measure of the diversity of a community that incorporates the phylogenetic relationships of species (Magurran 2004). Thus, it is possible to associate ecological and evolutionary approaches into spatial decision-making for conservation. The assumption that closely phylogenetic species have the same ecosystem roles is still an uncertain issue (Webb et al. 2002). Phylogenetic structure of communities depends on how the ecological characteristics evolved (Sobral and Cianciaruso 2012). Therefore, ecosystem functioning and stability are often correlated with changes in evolutionary process, producing several implications for ecological and human well-being on short-time scales (Alberti 2015).

Climate change is one of the main threats to global biodiversity (Thomas et al. 2004; Pereira et al. 2010), continuously promoting variations in physiological and ecological processes that directly affect the distribution and persistence of species (Stenseth et al. 2002; MacDonald et al. 2004; Huey et al. 2009). Some studies have addressed how climate change affects individual performances (Huang et al. 2013; Holt and Jorgensen 2015), demographic dynamics (Lukoscheck et al. 2013; Pomara et al. 2014), and species richness (Lemes and Loyola 2013; Ferro et al. 2014). Predictive outcomes have included adaptation to novel conditions (Quintero and Wiens 2013), expansion or retraction of species' extent of occurrence (Ferro et al. 2014; Lemes et al. 2014), isolation to climate refuges (Puschendorf et al. 2009), and in the worst cases, species extinctions 
74 (Thomas et al. 2004). Such climate change effects are the reasons there is a growing consensus that management

decisions for biodiversity conservation must take into account this phenomenon (Araújo and Rahbek 2007). Ecological niche models (ENMs), also referred to as species distribution models (SDMs) (Peterson et al. 2011; Rangel and Loyola 2012), have been used increasingly to estimate species ranges for future scenarios of climate change (Peterson et al. 2011). These models can be used to evaluate the current and future hotspots of functional and phylogenetic diversity (Thuiller et al. 2011; Loyola et al. 2013; Pio et al. 2014), working as efficient conservation tools (Del Toro et al. 2015). Ectothermic animals are highly susceptible to climate change (Pounds et al. 2006; Sinervo et al. 2010) due to the due to the interdependence of their behavioral-physiological functions in relation to the external environment (Ribeiro et al. 2012). More specifically, amphibians are very sensitive to environmental changes (Lourenço-de-Moraes et al. 2014) due to their metabolic features (Duellman and Trueb 1994), at high temperatures amphibians lose water to the atmosphere (Wells 2007) and may have local extinctions (Becker et al. 2007). Therefore, using ENMs may be an effective tool in predicting dispersion driven by climate change for amphibian species (Pie et al. 2013; Ribeiro et al. 2015), and may help to conserve these species.

The consequences of human activities go further than the loss of species and various studies reported losses of both evolutionary history and functional diversity at different landscapes (Purvis et al. 2000; Flynn et al. 2009; Mayfield et al. 2010). The Anthropocene is characterized by drastic climate change (especially warmer temperature), causing a massive defaunation (Dirzo et al. 2014). Facing this scenario, many species may be underestimated for their threat status (e.g., Ocampo-Peñuela et al. 2016). Carnaval et al. (2009) found three points of refuge during the Pleistocene, included areas of altitude in the mountain range of southeastern and northeastern in Atlantic Forest. Recent studies have suggested that areas of high altitude may be important refuges for vertebrates during the Anthropocene (Loyola et al. 2013; Lemes et al. 2014; Campos et al. 2017). In this context, we tested the hypothesis that the high elevation areas are refuges for amphibians and may maintain their contribution to ecosystem services and evolutionary potential. To address this hypothesis, we analysed the present and future distribution of taxonomic, functional and phylogenetic diversity of Atlantic Forest amphibian species. We correlated this diversity with altitude in both periods and analysed the retraction of species in the direction to higher areas. We also projected the potential species conservation status for 2080 based on the IUCN criteria. 
103

104

105

106

107

108

109

110

111

112

113

114

115

116

117

118

119

120

121

122

123

124

125

126

127

128

129

130

131

\section{Materials and Methods}

\section{Study area}

We focused our analyses on the Atlantic Forest Biodiversity Hotspot (Myers et al. 2000), which originally covered around 150 million ha with heterogeneous environmental conditions provided by a wide range of climatic belts and vegetation formations (Tabarelli et al. 2005; Ribeiro et al. 2009). This biome has an altitudinal range from sea level to the mountain chains of Serra do Mar and Serra da Mantiqueira (Cavarzere and Silveira 2012). This region has a longitudinal range with different forest compositions due to a diminishing gradient in rainfall from the coast to the interior, and a latitudinal range extending into tropical and subtropical environments (Ribeiro et al. 2009) (Fig. 1).

Spatial species data

We obtained spatial data of amphibian species through six steps: 1 . We built a dataset with all the species distributed in the Atlantic Forest according to Haddad et al. (2013); 2. We included the species occurrences records available through the Global Biodiversity Information Facility (GBIF: http://www.gbif.org); 3. We added maps of geographical ranges for each species from the IUCN Red List of Threatened Species (IUCN 2017); 4. We filtered out species that only occur in forested environments overlapping the spatial species data by the Atlantic Forest remnant map (SOS Mata Atlântica and INPE 2015), excluding all urban areas from the species distribution data; 5. We conducted complementary fieldwork in the major Atlantic Forest remnants of Brazil to supplement the dataset with observed functional traits, such as body size, reproductive mode, habitat, activity, poison patterns, habit and calling site (see Supplementary material Appendix 1, Fig. A1); and 6. We modelled the potential present and future distribution of species using ecological niche modelling.

We used the "Spatial Join" ArcGIS toolbox to transform species' spatial occurrences in matrices, matching rows from the join features to the target features based on their relative spatial locations. Then, we combined vector files based on expert knowledge of the species' ranges and forest remnant polygons into an overall coverage for species distribution modelling. We only considered spatial occurrences by those species where the distribution data intersected at least a grid cell (i.e. $\sim 10 \mathrm{~km} 2$ ). We used forest remnant data to meet the habitat patch requirements based on visual interpretation at a scale of 1:50,000, delimiting more than 260,000 forest remnants with a minimum mapping area of $0.3 \mathrm{~km} 2$. Therefore, we considered a species present in a cell if its spatial range intersected more than $0.3 \mathrm{~km} 2$. We also used the "Count Overlapping Polygons" ArcGIS 
132

133

134

135

136

137

138

139

140

141

142

143

144

145

146

147

148

149

150

151

152

153

154

155

156

157

158

159

160

161 toolbox to obtain the species richness at the spatial resolution assessed, removing all duplicate records from the analyses (i.e. repeated records of a species at a single locality).

Ecological niche modelling, species richness and turnover

We used ArcGIS 10 software (ESRI 2010) to build presence/absence matrices from the species distribution data by superimposing a grid system with cells of 0.1 latitude/longitude degrees, creating a network with 10,359 grid cells. In total, we assessed the geographical ranges of 453 amphibian species (five

Gymnophionas and 448 Anurans) covered by our grid system. We only considered a grid cell occupied by those species where the centre of the grid cell intersected with the species ranges. We also used the "Count

Overlapping Polygons" ArcGIS toolbox to obtain species richness at the spatial resolution assessed, removing all duplicate records from the analyses (i.e. repeated records of a species at a single locality).

Considering that species occurrence patterns are determined at large-scales by responses of organisms

to different environmental conditions (reflecting the Grinellian component of the ecological niche, sensu

Soberón 2007), we used ecological niche models (ENMs) to predict the distribution area of amphibian species in the Atlantic Forest. For this, we used the species occurrence matrix and the layers of climatic-environmental variables, resulting in a suitability matrix, which we used to model and map the potential distribution of each species evaluated.

We used the following bioclimatic variables in the modelling process: 1. annual mean temperature; 2. annual temperature range; 3 . precipitation of the wettest month; 4. precipitation of the driest month; and 5. precipitation of the warmest quarter. We obtained these variables for the present and future (mean of simulations for 2080-2100) from CMIP5 - Coupled Models Intercomparison Project Phase 5 (http://cmippcmdi.llnl.gov/cmip5/; and also at http://ecoclimate.org, see Lima-Ribeiro 2015), and downscaled to the resolution of 0.1 degrees. We also used altitude as predictor of richness and dispersion from the dataset available at WorldClim Global Climate Data (www.worldclim.org). We assumed altitude will remain constant through time, these permit to perform future predictions. For the future, we used the greenhouse gas concentration trajectory corresponded to the Representative Concentration Pathway (RCP) 4.5, which represents a moderated emission scenario within an optimistic context. This moderate scenario (RCP4.5) incorporates historical emissions pathways and land cover information to meet potential climate policies (Thomson et al. 2011). We choose this scenario believing to present better information than extreme scenarios (pessimistic RCP 8.5 or optimistic RCP 3). In the context, we used simulations provided by four Atmosphere-Ocean General Circulation 
Models (AOGCMs): CCSM, CNRM, MIROC and MRI, which were obtained from CMIP5 (Coupled Model Intercomparison Project - Phase 5) for the consensus model. Original data resolution varied from $1^{\circ}$ to $2.8^{\circ}$ (in longitude and latitude) and both present and future climate variables were re-scaled to fit our grid resolution. We performed four conceptually and statistically different ENMs based on presence data (i.e. only occurrences are known, absences are unknown) using the algorithms: 1. Bioclim (BIO, Busby 1991) based on bioclimatic envelope logic; 2. Gower Distance and Euclidean Distance (GD, EUD, Carpenter et al. 1993) based on environmental distance approach; 3. Maximum Entropy (ME, Phillips et al. 2006) and random forest (RF, Breiman 2001) based on machine learning technique; and 4. Ecological Niche Factor Analysis (ENFA, Hirzel et al. 2002) based on multivariate analysis, and Genetic Algorithm for Rule set Production (GARP, Stockwell and Noble 1992). Given the particularities of each model, they provided different predictions, generating uncertainties about which model is more appropriate to represent the geographical distribution of species (DinizFilho et al. 2009). To overcome this uncertainty and minimize errors, we employed the ensemble forecasting approach, which offers a consensus of multiple models (Araújo and New 2006). The main idea of ensemble forecasting is that different sources of errors will affect each niche model in different ways and, by obtaining a consensus result of these models, errors will tend to cancel each other out and produce a more trustworthy and conservative solution (Diniz-Filho et al. 2010). Assuming that the richness consensus model (CONS) reduces uncertainty and error associated with alternative ENMs, we interpreted only the range sizes from the CONS model.

We randomly partitioned presence and absence (pseudo-absence in the case of Maxent) data of each species into $75 \%$ for calibration (or training) and $25 \%$ for evaluation (or test); repeating this process 10 times by cross-validation for all models. For each ENM, we converted the continuous predictions of suitability into a binary vector of $1 / 0$ (presence and absence in each cell), finding the threshold that maximizes sensitivity and specificity values in the receiver operating characteristic (ROC). The ROC curve is generated by plotting the fraction of true positives vs. the fraction of false positives at various threshold settings. The distribution areas were estimated obtaining 280 predictions (7 models x 10 randomizations x 4 AOGCMs) for each species and time-period of climatic conditions (i.e. present and future). This allowed us to generate a frequency of projections in the ensemble. Then, we generated the frequency of projections weighted by the total sum of squares (TSS) statistics for the present and future (the best models according to this metric have more weight in our consensus projections). The TSS range from -1 to +1 , where values equal to +1 is a perfect prediction and values equal to or less than zero is a prediction no better than random (Allouche et al. 2006; Eskildsen et al. 
192

193

194

195

196

197

198

199

200

201

202

203

204

205

206

207

208

209

210

211

212

213

214

215

216

217

218

219

220

221

2013). We considered the species present only in cells where at least $50 \%$ of models retained in the ensemble point out the species as present. In our analyses, we obtained the CONS for each AOGCM and time period (present and 2080). Thus, we obtained the final maps of richness for present, future and turnover through the average of values projected by CONS for each grid cell - considering the different GCMs. We ran all models using the computational platform Bioensembles (Diniz-Filho et al. 2009), and mapped results using the software SAM v.4.0 (Rangel et al. 2010). To determine the species patterns of amphibians of the Atlantic Forest, we employed the modelling strategy at the community level of "predict first, assemble later" (sensu Overton et al. 2002), where the ranges of individual species are modelled one at a time as a function of environmental predictors and then overlapped to obtain the species richness.

We calculated species turnover between present and future species distributions in each cell according to formula $100 *((\mathrm{G}+\mathrm{L}) /(\mathrm{S}+\mathrm{G}))$. (Thuiller 2005), where " $\mathrm{G}$ "' refers to the number of species gained, " $\mathrm{L}$ " the number of species lost and " $\mathrm{S}$ " the species richness (contemporary) found in the cell.

\section{Functional and Phylogenetic Diversity}

We used the following functional traits according to Haddad et al. (2013), and supplemented with data from our fieldwork: 1 . body size; 2 . appendices (apodal and tetrapod); 3. activity (nocturnal, diurnal, and both); 4. toxicity (toxic, nontoxic, unpalatable, or bad odour); 5. habitat (forested area, open area, and both); 6. habit (arboreal, phytotelmate, terrestrial, cryptozoic, fossorial, rheophilic, semi-aquatic, and aquatic); 7. calling site (bamboo grove, swamp or lake, bromeliad, forest floor, tree canopy, caves or burrows, rock wall, backwater river, stream, river, shrubs, grasslands and not sings); and 8. reproductive mode (1 to 39 modes; see Haddad and Prado 2005; see Supplementary Material Appendix 1, Table A1 for traits details). Each functional trait contributes to ecosystem supporting services through direct and indirect changes on the ecosystem functions and their processes (Hocking and Babbitt 2014). For further details of specific functions and ecosystem supporting services of each one of the functional traits assessed, see Supplementary Material Appendix 1, Table A2.

We followed the protocol proposed by Petchey and Gaston (2006) to calculate functional diversity (FD): 1. construction of a species-trait matrix; 2. conversion of species-trait matrix into a distance matrix; 3. clustering distance matrix into a dendrogram (UPGMA); and 4. calculating functional diversity by summing dendrogram branch lengths of species community. To create the distance matrices, we used the method Gower distance proposed by Pavoine et al. (2009).

We used the phylogenetic diversity index (Faith 1992) to quantify the phylogenetic diversity (PD), 
222

223

224

225

226

227

228

229

230

231

232

233

234

235

236

237

238

239

240

241

242

243

244

245

246

247

248

249

250

251 which comprises the sum of the branches lengths of the phylogenetic tree of all species assessed and is often used in the assessment of phylogenetic diversity of con-current species (e.g., Rodrigues and Gaston 2002; Safi et al. 2011; Trindade-Filho et al. 2012). The PD index has appropriate ways of accounting for relatedness between taxa and evolutionary history in a conservation context (Pio et al. 2011).

We based the phylogenetic distance through 207 species nucleotide sequences obtained from GenBank (Benson et al. 2013) and provided by the National Center for Biotechnology Information (NCBI) (See Supplementary Material Appendix 1, Table A3). Following the protocol proposed by Pyron and Wiens (2011) in an extant amphibian phylogeny, we used 12 genes to produce a novel estimate phylogeny for the Atlantic Forest amphibians (i.e. 11,906 bp for each species), though three mitochondrial genes were included: cytochromeb (cytb), and the large and small sub-units of the mitochondrial ribosome genes (12S/16S); and nine nuclear genes: CX-C chemokine receptor type 4 (CXCR4), histone 3a (H3A), sodium-calcium exchanger (NCX1), proopiomelanocortin (POMC), recombination-activating gene 1 (RAG1), rhodopsin (RHOD), seventh-in-absentia (SIA), solute-carrier family 8 (SLC8A3), and tyrosinase (TYR). For the length-variable regions, we performed multiple pairwise comparisons by the online version of MAFFT v.6.8 and the G-INS-i algorithm (Katoh and Toh 2008). After, we put together alignments of all genes in the same alignment using the software SequenceMatrix 1.7.7 (Vaidya et al. 2011) to concatenate the supermatrix previously produced.

We analysed the phylogenetic relationships with Bayesian analyses in software BEAST 1.8 (Drummond and Rambaut 2007). We generated the phylogeny based on the combined data matrix using a HKY model of sequence evolution for one partition for all genes, under a Yule speciation process as the tree prior and an uncorrelated relaxed clock. After removal of the burn-in, we run the Yule process for 100 million generations, ensuring that the number of generations after convergence were sufficient assessed with Tracer v1.6 (Drummond and Rambaut 2007), combining the results with the use of Logcombiner 1.8 and Treeanotator 1.8 (Drummond and Rambaut 2007). We considered the nodes strongly supported if they received probability (pp) support values $\geq 0.95$. Thus, we reconstructed a new phylogenetic tree using the Mesquite software version 3.0 (Maddison and Maddison 2015).

To verify whether functional diversity (FD) and phylogenetic diversity (PD) was influenced by species richness (Devictor et al. 2010), we used independent swap null models (Gotelli and Entsminger 2001), according to the protocol proposed by Swenson (2014). The values provided by such models are more sensitive to preserving both site diversity and species frequency of occurrence while randomizing the pairs of species/sites, which ensure that patterns of trait assembly do not simply reflect differential occurrence of particular species 
252 (Ackerly et al. 2006; Swenson 2014) for present and future times. The null model is totally independent of the

253 species richness of an assemblage (Swenson 2014), which provides expected values at different species richness

254 levels (Mouchet et al. 2010). Hence, we tested if the functional and phylogenetic diversity were higher, equal or

255 lower than expected by chance for each grid cell (random or non-random pattern), assuming a random

256 distribution in which every species could occupy any grid cell in the biome. For each pruning event (present and

257 future), we computed 1,000 replicates of random remaining PD and FD, allowing us to obtain a $P$-value of

258 predicted PD and FD as compared to the distribution of the random replicates. All analyses were performed

259 using the packages "ade4", "picante", "FD” and "vegan" through the R software (R Development Core Team

260 2017).

261

262

Species Richness, and Functional and Phylogenetic Diversity vs. Topography and Spatial References

We used correlation matrices to compare the topographic patterns and spatial references (altitude and latitude) to the values obtained by the richness consensus model for CONS, Turnover, FD and PD in each grid cell for present and future time (2080). Thus, we correlated the values obtained for CONS, FD and PD with altitude, and the turnover values with altitude and latitude using simple linear regression models.

We used correlation matrices to compare the topographic patterns and bioclimatic variables (altitude vs bioclimatic variables) to the values in each grid cell for present and future conditions. Using multiple linear regression models for the correlation matrices, we compared the following bioclimatic variables: 1 . annual mean temperature; 2. annual temperature range; 3 . precipitation of the wettest month; 4 . precipitation of the driest month; and 5. precipitation of the warmest quarter.

\section{Threat status of species facing climate change}

From the individual range sizes (i.e. number of occupied cells) of each species in present and future, we estimated the threat status of amphibian species by 2080, fitting the species' extent of occurrence under the IUCN's criterion B1 (IUCN, 2015). We considered the following threat categories: 1. Extinct $(\mathrm{EX})=0 \mathrm{~km}^{2}, 2$. Critically Endangered $(\mathrm{CR})=$ occurrence $<100 \mathrm{~km}^{2} ; 3$. Endangered $(\mathrm{EN})=$ occurrence $<5,000 \mathrm{~km}^{2} ; 4$ Vulnerable $(\mathrm{VU})=$ occurrence $<20,000 \mathrm{~km}^{2}$; and 5. Nonthreatened $(\mathrm{NT})=$ occurrence $>20,000 \mathrm{~km}^{2}$. 
282

283

284

285

286

287

288

289

290

291

292

293

294

295

296

297

298

299

300

301

302

303

304

305

306

307

308

309

310

311
$30 \%$ for the projected time interval; and 5 . the species whose loss is estimated at below $30 \%$ for the projected time interval.

\section{Results}

The results from the total sum of squares (TSS) for most species presented average and standard deviation of $0.61 \pm 0.11$, indicating relatively high fit model. The overlap of individual species ranges generated by the CONS model suggested that the highest species richness values were restricted almost entirely to the easterncentral portion of the Atlantic Forest in the present times (Fig. 2, 3 and 4). Species richness pattern showed no significant relationships with the altitude $\left(\mathrm{r}^{2}=0.000, P=0.182\right.$, Fig. $\left.4 \mathrm{c}\right)$. The future predictions produced by CONS from different AOGCMs pointed out the losses of climatically suitable areas in this region by 2080, with the species richness directed to the east-central portion of the Atlantic Forest. In this case, species richness increased toward higher altitude $\left(r^{2}=0.132, P<0.001\right.$ Fig. $\left.3 d\right)$. In general, CCSM and MRI showed two distinct species-rich areas and CNRM and MIROC produced more homogeneous results, with the latter being more restrictive (Fig. 2a-d). By combining the results of the AOGCMs in a full ensemble model, we found that in the future the species richness peaks are likely to be restricted to a reduced portion of the central-eastern region of the biome in locations closer to the mountain regions of the Atlantic Forest (Fig. 3).

Temporal turnover was high after the results of AOGCMs were combined in a full ensemble model. Changes in species composition are predicted to be greater on the western edge and on the northeastern edge of the biome. Higher turnover rates were found at lower latitudes $\left(\mathrm{r}^{2}=0.308, P<0.001\right)$ and lower altitudes $\left(\mathrm{r}^{2}=\right.$ 0.307, $P<0.001)$ (see Fig. 4a-c).

Our results showed high Functional Diversity (FD) in the regions of the eastern Atlantic Forest with the highest rates in the east-central region rising to the northeast in the present time (Fig. 5a, c). In 2080, these values will decrease from 17.30 to 15.53 at its maximum value (Fig. 5b), and will have a significant higher loss in areas of lower altitudes (Fig. 5b, d). High rates of FD were found mainly in the south of Bahia to the south of São Paulo states. High values of FD were correlated with high altitude for both the present $\left(\mathrm{r}^{2}=0.004, P<\right.$ 0.001 , Fig. 5c) and future $\left(r^{2}=0.101, P<0.001\right.$, Fig. 5d).

The highest values of Phylogenetic Diversity (PD) in the present time are distributed in the east-central region, mainly in the region of Serra do Mar rising to the Central Corridor and in a small part of Pernambuco (in high altitude areas) (Fig. 6a, c). For 2080, these values will decrease from 5.65 to 5.44 at its maximum value (Fig. 6b), which will dramatically decrease in the south and north of Bahia, increasing towards the south of the 
312 Serra do Mar mountain chain. Higher-altitude regions will be replaced by significant values in the future $(P<$

313 0.001, Fig. 6d). Built null models for FD and PD in present and future times showed different values than

314 expected by chance $(P<0.001)$, indicating a non-random pattern of FD and PD. FD and PD were highly

315 correlated (present $\mathrm{r}^{2}=0.91, P<0.001$; future $\mathrm{r}^{2}=0.94, P<0.001$ ), based on comparison of the CONS consensus

316 model (present FD $-\mathrm{r}^{2}=0.87, P<0.001, \mathrm{PD}-\mathrm{r}^{2}=0.89, P<0.001$; future FD $-\mathrm{r}^{2}=0.86, P<0.001, \mathrm{PD}-\mathrm{r}^{2}=$

$3170.84, P<0.001)$. Therefore, the loss of species richness in the future may be accompanied by the loss of FD and

318 PD (Fig. 7).

319 The bioclimatic variable correlation with altitude was correlated (present $r^{2}=0.60, P<0.001$; future $r^{2}=$

$3200.60, P<0.001$ ), but the only bioclimatic variable with positively relation was the precipitation of the wettest

321 month (Table 1). The change of bioclimatic variables in high altitude areas can be lower in the future than in the

322 low altitude areas. It may leave the higher altitudes more favourable to amphibians in the future.

323 The prediction of massive habitat suitability losses under climate change will negatively affect most

$324(60 \%)$ amphibians of the Atlantic Forest and most will be subjected to some level of threat by 2080 (Fig. 8).

325 According to our estimations under the IUCN's criterion B1, 40\% ( $\mathrm{n}=181 \mathrm{spp}$.) of the species will be not

326 threatened. However, $15 \%(n=62 \mathrm{spp}$.) of the species will experience less than $30 \%$ reduction from the original

327 distribution area by considering the projections for a moderate carbon emission scenario. Our results also

328 indicated that $21.6 \%(n=97 \mathrm{spp}$.) of the species are expected to be extinct from the biome by 2080 . The

329 summary of the impacts of future climatic alterations on each individual species is given in Supplementary

330 Material Appendix 1, Table A4. Our results showed that the functional traits can have losses of $30 \%$ on average.

331 The trait habit was that most show reduction and species with the subtrait phytotelmata cannot occur (Fig. 9).

332

\section{Discussion}

334 Our data showed a dramatic reduction of species range (CONS, PD and FD) for 2080. High rates of turnover in 335 the lower latitudes and lower rates in the high altitudes strengthen the mountains of Atlantic Forest as climatic 336 refuges (Randin et al. 2009; Araújo et al. 2011). The persistence of the species in their original ranges depend on 337 their degree of physiological and phenotypic plasticity, antipredator mechanisms, reproductive mode, and evolutionary adaptation to environmental change (Holt 1990; Visser 2008; Toledo et al. 2012; Urban et al. 2014;

339 Ferreira et al. 2016; Lourenço-de-Moraes et al. 2016, 2018). As result, some species have increased their ranges,

340 but with low range in the future. For instance, opportunistic species adapted to warmer and drier environments

341 had a spatial range expansion (e.g., Rhinella crucifer, Dendropsophus branneri, Leptodactylus troglodytes and 
342

343

344

345

346

347

348

349

350

351

352

353

354

355

356

357

358

359

360

361

362

363

364

365

366

367

368

369

370

371

Siphonops annulatus). Species that live in high altitudes and high latitudes had their ranges little affected, due to the low temperature increase and high rainfall in these localities. Brachycephalus brunneus, a species that due to its morphology and great dependence on abiotic factors (i.e., temperature and rainfall - 1,300 m a.s.1.; Ribeiro et al. 2005), had low range changes in our model, which enable it to remain in the future. However, species of this same genus that occur in the north portion of the Atlantic Forest, such as B. pulex (Napoli et al. 2011), also can become extinct according to the same model.

Our results showed that FD and PD have high correlation among themselves and a non-random pattern of species composition for both present and future times. This pattern suggests that environmental factors may act as a filter that does not allow the co-existence of similar species (Diamond 1975; Weiher and Keddy 1999). In addition, historical factors provided biogeographic barriers acting to determine the regional bank of some species assemblages (Ricklefs and Schluter 1993). We revealed three major areas of FD and PD for the present time, which are located in the mountains of the Serra do Mar, the Central Corridor of the Atlantic Forest and the high altitude areas of Pernambuco state. Carnaval et al. (2009) pointed out three climatic refuges for amphibians during the Pleistocene: 1. Southern Bahia state (located in the Central Corridor of the Atlantic Forest); 2.

Pernambuco state; 3. East-north region of São Paulo (i.e., Serra do Mar). We showed higher rates of PD and FD in these areas, supporting Carnaval et al. (2009) hypothesis. Our results also suggested climatic refuges in the Espírito Santo state, the Serra da Mantiqueira region that corresponds to the South of Minas Gerais state, and the South of Serra do Mar that corresponds to the east of Paraná state. In the future (i.e., 2080), these same areas will continue as climatic refuges, mainly in higher altitudes. Our model showed that species may have suitable habitat in higher latitudes and altitudes (see Fig. 3 and 4). Species with access to mountainous regions may migrate to higher altitude areas, which have lower temperatures (Colwell et al. 2008), and in the case of the Atlantic Forest, should retain greater humidity due to better-preserved forests cover (Ribeiro et al. 2009). Our data showed that altitude areas are positively correlated with increased rainfall mainly in the drier months. In addition, we suggested that areas of higher altitude will have lower temperature under climate change, making these areas suitable for species survival. Therefore, high altitude areas can be associated to amphibian-friendly climatic variables using forecast scenarios.

Loyola et al. (2013) indicated high values of PD for amphibians in the Atlantic Forest in both the present and future (i.e., 2080). Our findings contradict these values, indicating low PD values and significant correlations may result in the loss of richness consensus model (CONS) for the future. However, our results corroborate the data obtained by Thuiller et al. (2011), which showed that the loss of species richness may be 
372

373

374

375

376

377

378

379

380

381

382

383

384

385

386

387

388

389

390

391

392

393

394

395

396

397

398

399

400

401 accompanied by the loss of PD. Furthermore, we also found that the loss of species richness in the future will result in the loss of FD.

The historical loss and their relationships do not reflect the actual proportion of loss in relation to the conservation of species. FD reflected better the loss of ecological functions and evolutionary perspectives, because similar species from similar phylogenetic clades may not coexist due to possible competitive exclusion (Arnam et al. 2016). However, closely phylogenetic species may have different roles on the ecosystem functioning (Webb et al. 2002; Gomez et al. 2010). In these cases, the loss of phylogenetically similar species may coexist and may have greater losses in processes and ecosystem services (Webb et al. 2002). By framing evolutionary ecology into conservation science, we revealed that phylogenetic metrics can be relevant tools for functional landscape planning for threatened amphibian species.

According to our results, $60 \%$ of the studied species will be threatened or extinct by 2080 . It is highly concerning that $92 \%$ of the species of our study are not included in any threatened status by the Brazilian Red list (Supplementary material Appendix 1, Table A4). Moreover, amphibian species from Atlantic Forest protected areas are more threatened by extinction than in other Brazilian protected networks (Campos et al. 2016). The Atlantic Forest was destroyed severely and fragmented, resulting in only $9-12 \%$ of its original formation remaining (Ribeiro et al. 2009). The current distributions of species provided by IUCN do not undergo any type of biological filter (e.g., urban and rural areas). The proximity of the protected areas to urban environmental, also negatively affect the local species richness (Lourenço-de-Moraes et al. 2018). Because of this, the analysed data can lead to overestimations, and the results for the future may be even more alarming. Many biotic and abiotic factors can influence the richness and composition of species in an ecosystem (Diamond 1975). Amphibians are particularly sensitive to environmental changes, and depending on the species, dispersion may be difficult because of its specializations and diminutive size (Crump 2010; Early and Sax 2011; Lourenço-de-Moraes et al. 2012, 2014). The main reason behind our choice by the consensus modelling approach was to look for a straightforward combination of environmental predictors that best explains the presence-only species distribution across forest remnants. Given that temperature and humidity are the main climate components that directly affect the biology of amphibians (Carey and Alexander 2003), we selected these variables along altitudinal gradients to provide a reasonably good representation of the species present in the forest remnants.

The use of various algorithms to reach a better consensus model have been demonstrated as an effective strategy to reach outcomes closer to reality, and it is one of the keys to understanding how communities can 
402

403

404

405

406

407

408

409

410

411

412

413

414

415

416

417

418

419

420

421

422

423

424

425

426

427

428

429

430

431

respond to climate change (Araújo and New 2006; Marmion et al. 2009). Therefore, our consensus model showed useful results to plan conservation actions in relation to spatial and temporal patterns in ecology and evolution. We introduced a new conservation framework that has sought to understand the functioning of ecosystems from the amphibian-climate refuges in an age of extinction.

Studies in the Atlantic Forest have been warning about the need to invest in protected areas at high altitudes (Lemes et al. 2013; Loyola et al. 2013), mainly in the areas of Serra do Mar and south of Bahia (Carnaval et al. 2009; Campos et al. 2017; Campos and Lourenço-de-Moraes 2017). Considering the dramatic evolutionary and ecological loss showed in this study, we suggest four large areas as priority for conservation in the Atlantic Forest: the Serra do Mar, the Serra da Mantiqueira, the Central Corridor and areas of high altitude in the Pernambuco state.

Amphibians are very sensitive to climate change mainly due to their metabolic characteristics. Dispersal across disturbed areas may be unfeasible for most species. The management of the already conserved areas, inserted in the points of climatic refuges, as well as areas of connections to these refuges is indispensable for the conservation of the amphibians. Knowing the first climatic refuges facilitates the decision making to conserve the amphibians during the climatic changes avoiding mass extinctions.

\section{References}

Ackerly DD, Schwilk DW, Webb CO (2006) Niche evolution and adaptive radiation: testing the order of trait divergence. Ecology 87:50-61

Alberti M (2015) Eco-evolutionary dynamics in an urbanizing planet. Trends Ecol. Evol. 30:114-126

Allouche O, Tsoar A, Kadmon R (2006) Assessing the accuracy of species distribution models: prevalence, kappa and the true skill statistic (TSS). J App Ecol 43:1223-1232 doi:10.1111/j.13652664.2006.01214.x

Arnan X, Cerdá X, Retana J (2016) Relationships among taxonomic, functional, and phylogenetic ant diversity across the biogeographic regions of Europe. Ecography 39:001-010

Araújo MB, Cabeza M, Thuiller W, Hannah L, Williams PH (2004) Would climate change drive species out of reserves? An assessment of existing reserve-selection methods. Glob Change Biol 10:1618-1626 doi:10.1111/j.1365-2486.2004.00828.x

Araújo MB, New M (2006) Ensemble forecasting of species distributions. Trends Ecol Evol 22:43-47 doi:10.1016/j.tree.2006.09.010 
432

433

434

435

436

437

438

439

440

441

442

443

444

445

446

447

448

449

450

451

452

453

454

455

456

457

458

459

460

Araújo MB, Rahbek C (2007) Conserving biodiversity in a world of conflicts. J Biog 34:199-200 doi:10.1111/j.1365-2699.2006.01687.x

Araújo MB, Alagador D, Cabeza M, Nogués-Bravo D, Thuiller W (2011) Climate change threatens European conservation areas. Ecol Letters 14:484-492

Bambach RK (2006) Phanerozoic biodiversity mass extinctions. Annu Rev Earth Planet Sci 34:127-155

Barnosky AD, Matzke N, Tomiya S, Wogan GOU, Swartz B, Quental TB Marshall C, McGuire JL, Lindsey EL, Maguire KC, Mersey B, Ferrer EA (2011) Has the Earth's sixth mass extinction already arrived? Nature 471:51-57

Benson DA, Cavanaugh M, Clark K, Karsch-Mizrachi I, Lipman DJ, Ostell J, Sayers EW (2013) GenBank Nuc Aci Res 41:36-42

Becker CG, Fonseca CR, Haddad CFB, Batista RF, Prado PI (2007) Habitat split and the global decline of amphibians. Science 318:1775-1777

Busby Jr (1991) BIOCLIM - A bioclimate analysis and prediction system. In: Nature Conservation: Cost Effective Biological Surveys and Data Analysis. Margules, C. R. and Austin, M. P. (eds.) Melbourne: CSIRO, pp. 64-68

Bush MB (1994) Amazonian speciation: a necessarily complex model. J Biog 21:5-17 doi: 10.2307/2845600

Bush MB, Oliveira PE (2006) The rise and fall of the refugial hypothesis of of Amazonian speciation: a paleoecological perspective. Biot Neot 6: http://dx.doi.org/ 10.1590/S1676-06032006000100002.

Bush MB, Gosling WD, Colinvaux PA (2011) Climate and vegetation change in the lowlands of the Amazon Basin. In: Tropical Rainforest Responses to Climatic Change, $2^{\circ}$ Edition. Bush, M., Flenley, J. and Gosling, W. (eds). Springer-Praxis Books, New York, New York, pp. 61-84

Breiman L (2001) Random Forests. Mach Lear 45:5-32 http://dx.doi.org/10.1023/A:1010933404324

Campos FS, Llorente GA, Rincón L, Lourenço-de-Moraes R, Solé M (2016) Protected areas network and conservation efforts concerning threatened amphibians in the Brazilian Atlantic Forest. W Ecol 16:9-12

Campos FS, Lourenço-de-Moraes R (2017) Amphibians from the mountains of the Serra do Mar Coastal Forest, Brazil. Herpetol Notes 10:547-560

Campos FS, Lourenço-de-Moraes R, Llorente GA, Sole M (2017) Cost-effective conservation of amphibian ecology and evolution. Science Adv 3(6):e1602929 doi: 10.1126/sciadv.1602929.

Carey C, Alexander MA (2003) Climate change and amphibian declines: is there a link? Div Dist 9:111-121 
Carnaval AC, Hickerson MJ, Haddad CFB, Rodrigues MT, Moritz C (2009) Stability predicts genetic diversity in the Brazilian Atlantic forest hotspot. Science 323:785-789

Carpenter G, Gillison AN, Winter J (1993) DOMAIN : a flexible modelling procedure for mapping potential distributions of plants and animals. Biodivers Conserv 2:667-680

Cardinale BJ, Matulich KL, Hooper DU, Byrnes JE, Duffy E, Gamfeldt L, Balvanera P, O'Connor MI, Gonzalez A (2011) The functional role of producer diversity in ecosystems. Am J Bot 98:572-592

Cavarzere V, Silveira LF (2012) Bird species diversity in the Atlantic Forest of Brazil is not explained by the Mid-domain Effect. Zoologia 29:285-292 doi:10.1590/S1984-46702012000400001

Colwell RK, Brehm G, Cardelús C, Gilman A, Longino JT (2008) Global warming, elevational range shifts, and lowland biotic attrition in the wet tropics. Science 322:258-261

Crump ML (2010) Amphibian diversity and life history. In: Amphibian Ecology and Conservation A handbook of techniques. Dodd Jr., C. K. (ed.) Oxford: Oxford University Press, pp. 1-19

Del Toro I, Silva RR, Ellison AM (2015) Predicted impacts of climatic change on ant functional diversity and distributions in eastern North American forests. Div Dist 21:781-791

Devictor V, Mouillot D, Meynard C, Jiguet F, Thuiller W, Mouquet N (2010) Spatial mismatch and congruence between taxonomic, phylogenetic and functional diversity: the need for integrative conservation strategies in a changing world. Ecol Lett 13:1030-1040

Diamond JM (1975) Assembly of species communities. In: Ecology and evolution of communities. Cody, M. L. and Diamond, J. (eds.). Cambridge: Harvard University Press, pp. 342-444

Diniz-Filho JAF, Bini ML, Rangel TF, Loyola RD, Hof C, Nogués-Bravo D, Araújo MB (2009) Partitioning and mapping uncertainties in ensembles of forecasts of species turnover under climate change. Ecography 32:897-906 doi:10.1111/j.1600-0587.2009.06196.x

Diniz Filho JAF, Ferro VG, Santos T, Nabout JC, Dobrovolski R, De Marco Jr, P (2010) The three phases of the ensemble forecasting of niche models : geographic range and shifts in climatically suitable areas of Utetheisa ornatrix. Rev Bras Ent 54:339-349

Dirzo R, Young HS, Galetti M, Ceballos G, Isaac NJB, Collen B (2014) Defaunation in the Anthropocene. Science 345:401-406 DOI:10.1126/science.1251817

Drummond AJ, Rambaut A (2007) BEAST: Bayesian evolutionary analysis by sampling trees. Evol Biol 7:214 DOI: $10.1186 / 1471-2148-7-214$

Duellman WE, Trueb L (1994) Biology of Amphibians. McGraw Hill, New York. 
491

492

493

494

495

496

497

498

499

500

501

502

503

504

505

506

507

508

509

510

511

512

513

514

515

516

517

518

519

520

Early R, Sax DF (2011) Analysis of climate paths reveals potential limitations on species range shifts. Ecol Lett 14:1125-1133

Environmental Systems Research Institute ESRI (2011) Arcgis Software: Version10.1. ESRI, Redlands, CA

Eskildsen A, Le Roux PC, Heikkinen RK, Hoye TT, Kissling WD, Poyry J, Wisz MS, Luoto M (2013) Testing species distribution models across space and time: high latitude butterflies and recent warming. Global Ecol Biogeogr 22:1293-1303

Faith DP (1992) Conservation evaluation and phylogenetic diversity. Biol Cons 61:1-10

Ferreira RB, Beard KH, Crump ML (2016) Breeding guild determines frog distributions in response to edge effects and habitat conversion in the Brazil's Atlantic Forest. PLoS One 11:e0156781 doi:10.1371/journal.pone.0156781

Ferro VG, Lemes P, Melo AS, Loyola R (2014) The reduced effectiveness of protected areas under climate change threatens atlantic forest tiger moths. PLoS One 9:e107792 doi:10.1371/journal.pone.0107792

Flynn DF, Gogol-Prokurat M, Nogeire T, Molinari N, Richers BT, Lin BB, Simpson N, Mayfield MM, DeClerck F (2009) Loss of functional diversity under land-use intensification across multiple taxa. Ecol Lett 12:22-33

Gómez JP, Bravo GA, Brumfield RT, Tello JG, Cadena CDA (2010) A phylogenetic approach to disentangling the role of competition and habitat filtering in community assembly of Neotropical forest birds. J Anim Ecol 79:1181-1192

Gotelli NJ, Entsminger GL (2001) Swap and fill algorithms in null model analysis: rethinking the knight's tour. Oecologia 129:281-291 DOI 10.1007/s004420100717

Haddad CFB, Prado CPA (2005) Reproductive modes in frogs and their unexpected diversity in the Atlantic forest of Brazil. Bioscience 55:207-217

Haddad CFB, Toledo LF, Prado CPA, Loebmann D, Gasparini JL, Sazima I (2013) Guia dos anfíbios da Mata Atlântica: diversidade e biologia. Anolis Books, São Paulo

Haffer J (1969) Speciation in Amazon forest birds. Science 165:131-137

Hirzel AH, Hausser J, Chessel D, Perrin N (2002) Ecological-niche factor analysis: how to compute habitatsuitability maps without absence data? Ecology 83:2027-2036

Huey RB, Deutsch CA, Tewksbury JJ, Vitt LJ, Hertz PE, Alvarez-Pérez HJ, Garland TJr (2009) Why tropical forest lizards are vulnerable to climate warming. Proc R Soc B Biol Sci 276:1939-1948 doi:10.1098/rspb.2008.1957 
521 Holt RD (1990) The microevolutionary consequences of climate change. Trends Ecol Evol 5:311-315

522 Holt RE, Jørgensen C (2015) Climate change in fish : effects of respiratory constraints on optimal life history

523 and behavior. Biol Lett 11:20141032 doi:http://dx.doi.org/10.1098/rsbl.2014.1032

524 Hocking DJ, Babbitt KJ (2014) Amphibian contributions to ecosystem services Herpet Cons Biol 9:1-17

525 Huang S-P, Chiou C-R, Lin T-E, Tu M-C, Lin C-C, Porter WP (2013) Future advantages in energetics, activity

526 time, and habitats predicted in a high-altitude pit viper with climate warming. Funct Ecol 27:446-458

527 doi:10.1111/1365-2435.12040

528 Katoh K, Toh H (2008) Recent developments in the MAFFT multiple sequence alignment program. Brief

$529 \quad$ Bioinform 9:286-298

530 International Union for Conservation of Nature (2015) IUCN Red List of Threatened Species: Version 2015.4,

$531<$ ww.iucnredlist.org/technical-documents/spatial-data $>$

532 Jablonski D (1994) Extinctions in the fossil record. Phil Trans R Soc Lond Ser B 344:11-17

533 Lima-Ribeiro MS, Varela S, González-Hernández J, Oliveira G, Diniz-Filho JAF, Terribile LC (2015)

534 Ecoclimate: a Database of climate data from multiple models for past, present, and future for

535 macroecologists and biogeographers. Biodivers Inform 10:1-21. doi:10.17161/bi.v10i0.4955

536 Lemes P, Loyola RD (2013) Accommodating species climate-forced dispersal and uncertainties in spatial

537 conservation planning. PLoS One 8:e54323 doi:10.1371/journal.pone.0054323

538 Lemes P, Melo AS, Loyola RD (2014) Climate change threatens protected areas of the Atlantic Forest. Biodiver

539 Conserv 23:357-368 doi:10.1007/s10531-013-0605-2

540 Loyola RD, Lemes P, Nabout JC, Trindade-Filho J, Sagnori MD, Dobrovolski R, Diniz-Filho JAF (2013) A

541 straightforward conceptual approach for evaluating spatial conservation priorities under climate change.

542 Biodiver Conserv 22:483-495 doi:10.1007/s10531-012-0424-x

543 Lourenço-de-Moraes R, Sole M, Toledo LF (2012) A new species of Adelophryne Hoogmoed and Lescure 1984

544 (Amphibia: Anura: Eleutherodactylidae) from the Atlantic forest of southern Bahia, Brazil. Zootaxa

$545 \quad 3441: 59-68$

546 Lourenço-de-Moraes R, Ferreira RB, Fouquet A, Bastos RP (2014) A new diminutive frog species of

547 Adelophryne (Amphibia: Anura: Eleutherodactylidae) from the Atlantic Forest, southeastern Brazil.

$548 \quad$ Zootaxa 3846:348-360 
549 Lourenço-de-Moraes R, Ferreira RB, Mira-Mendes CCV, Zocca CZ, Medeiros T, Ruas DS, Rebouças R, Toledo

550 LF, Brodie Jr ED, Solé M (2016) Escalated antipredator mechanisms of two neotropical marsupial

551 treefrogs. Herpetol J 26:237-244

552 Lourenço-de-Moraes R, Malagoli LR, Guerra VB, Ferreira RB, Affonso IP, Haddad CFB, Sawaya RJ, Bastos

553 RP (2018) Nesting patterns between Neotropical species assemblages: Can reserves in urban areas be

554 failing to protect anurans? Urban Ecosyst https://doi.org/10.1007/s11252-018-0767-5

555 Lukoschek V, Beger M, Ceccarelli D, Richards Z, Pratchett M (2013) Enigmatic declines of Australia's sea

556 snakes from a biodiversity hotspot. Biol Cons 166:191-202 doi:10.1016/j.biocon.2013.07.004

557 McDonald PG, Olsen PD, Cockburn A (2004) Weather dictates reproductive success and survival in the

558 Australian brown falcon Falco berigora. J Anim Ecol 73:683-692

559 Maddison WP, Maddison DR (2015) Mesquite: a modular system for evolutionary analysis: Version 3.04.

$560 \quad$ Mesquite Project Team $<$ http://mesquiteproject.org.>

561 Magurran AE (2004) Measuring biological diversity. Blackwell, Oxford.

562 Mayfield MM, Bonser SP, Morgan JW, Aubin I, McNamara S, Vesk PA (2010) What does species richness tell

563 us about functional diversity? Predictions and evidence for responses of species and trait diversity to

$564 \quad$ land use change. Global Ecol Biogeogr 19:423-431

565 Marmion M, Parviainen M, Luoto M, Heikkinen RK, Thuiller W (2009) Evaluation of consensus methods in

566 predictive species distribution modelling. Divers Distrib 15:59-69

567 Mayr E, O’hara RJ (1986) The biogeographic evidence supporting the Pleistocene forest refuge hypothesis.

$568 \quad$ Evolution 40:55-67 doi: $10.2307 / 2408603$

569 Myers N, Mittermeier RA, Mittermeier CG, Fonseca GA, Kent J (2000) Biodiversity hotspots for conservation

$570 \quad$ priorities. Nature 403:853-858

571 Montoya J M, Raffaelli D (2010) Climate change, biotic interactions and ecosystem services. Phil Trans R Soc

$572 \quad$ Ser B 365:2013-2018 doi:10.1098/rstb.2010.0114

573 Mouchet M, Villéger S, Mason NWH, Mouillo D (2010) Functional diversity measures: an overview of their

574 redundancy and their ability to discriminate community assembly rules. Funct Ecol 24:867-876

575 Napoli MF, Caramaschi U, Cruz CAG, Dias IR (2011) A new species of flea-toad, genus

576 Brachycephalus Fitzinger (Amphibia: Anura: Brachycephalidae), from the Atlantic rainforest of

577 southern Bahia, Brazil. Zootaxa 2739:33-40 
578 Ocampo-Peñuela N, Jenkins CN, Vijay V, Li BV, Pimm SL (2016) Incorporating explicit geospatial data shows 579 more species at risk of extinction than the current Red List. Science Advanc 2:e1601367 doi:

$580 \quad 10.1126 /$ sciadv. 1601367

581 Overton JM, Stephens RTT, Leathwick JR, Lehmann A (2002) Information pyramids for informed biodiversity 582 conservation. Biodivers Conserv 11:2093-2116 doi:10.1023/A:1021386426790

583 Paradis E, Claude J, Strimmer K (2004) APE: Analyses of phylogenetics and evolution in R language.

$584 \quad$ Bioinformatics 20:289-290

585 Pavoine S, Vallet J, Dufour AB, Gachet S, Daniel H (2009) On the challenge of treating various types of 586 variables: application for improving the measurement of functional diversity. Oikos 118:391-402 doi:10.1111/j.1600-0706.2008.16668.x.

Pereira HM, Leadley PW, Proença V, Alkemade R, Scharlemann JP, Fernandez-Manjarrés JF, Araújo MB, Balvanera P, Biggs R, Cheung WW, Chini L, Cooper HD, Gilman EL, Guénette S, Hurtt GC, Huntington HP, Mace GM, Oberdorff T, Revenga C, Rodrigues P, Scholes RJ, Sumaila UR, Walpole M (2010) Scenarios for global biodiversity in the 21st century. Science 330:1496-1501 doi:10.1126/science. 1196624

Petchey OL, Gaston KJ (2006) Functional diversity: back to basics and looking forward. Ecol Lett 9:741-758

Peterson AT, Soberón J, Pearson RG, Anderson RP, Martínez-Meyer E, Nakamura M, Araújo MB (2011) Ecological niches and geographical distributions. Princeton, New Jersey: Princeton University Press.

Pie MR, Meyer ALS, Firkowski CR, Ribeiro LF, Bornschein MR (2013) Understanding the mechanisms underlying the distribution of microendemic montane frogs (Brachycephalus spp, Terrarana: Brachycephalidae) in the Brazilian Atlantic Rainforest Ecol Model 250:165-176

Pio DV, Broennimann O, Barraclough TG, Reeves G, Rebelo AG, Thuiller W, Guisan A, Salamin N (2011)

600

601

602

Pio D, Engler R, Linder H, Monadjem A, Cotterill F, Taylor P, Schoeman C, Price B, Villet M, Eick G, Salamin 603 604 N, Guisan A (2014) Climate change effects on animal and plant phylogenetic diversity in southern Africa. Glob Change Biol 20:1538-1549

605 Phillips SJ, Anderson RP, Schapire RE (2006) Maximum entropy modeling of species geographic distributions. 606 Ecol Model 190:231-259 doi:10.1016/j.ecolmodel.2005.03.026 
607 Pyron A, Wiens JJ (2011) A large-scale phylogeny of Amphibia including over 2800 species, and a revised 608 classification of extant frogs, salamanders, and caecilians. Mol Phyl Evol 61:543-583

609 Pomara LY, Ledee OE, Matin KJ, Zuckerberg B (2014) Demographic consequences of climate change and land 610 cover help explain a history of extirpations and range contraction in a declining snake species. Glob

$611 \quad$ Change Biol 20:2087-2099 doi:10.1111/gcb.12510

612 Pounds JA, Bustamante MR, Coloma LA, Consuegra JA, Fogden MP, Foster PN, La Marca E, Masters

613 KL, Merino-Viteri A, Puschendorf R, Ron SR, Sánchez-Azofeifa GA, Still CJ, Young BE (2006)

614 Widespread amphibian extinctions from epidemic disease driven by global warming. Nature 439:161-

$615 \quad 167$ doi:10.1038/nature04246

616 Purvis A, Agapow PM, Gittleman JL, Mace GM (2000) Non-random extinction and the loss of evolutionary

617 history. Science 288:328-330

618 Puschendorf R, Carnaval AC, VanDerwal J, Zumbado-Ulate H, Chaves G, Bolaños F, Alford RA (2009)

619 Distribution models for the amphibian chytrid Batrachochytrium dendrobatidis in Costa Rica:

620 proposing climatic refuges as a conservation tool. Divers Distrib 15:401-408 doi:10.1111/j.1472-

$621 \quad 4642.2008 .00548 . x$

622 Prather MJ, Holmes CD, Hsu J (2012) Reactive greenhouse gas scenarios: Systematic exploration of

623 uncertainties and the role of atmospheric chemistry. Geophys Res Lett 39:L09803

624 doi:10.1029/2012GL051440

625 Quintero I, Wiens JJ (2013) Rates of projected climate change dramatically exceed past rates of climatic niche 626 evolution among vertebrate species. Ecol Lett 16:1095-1103 doi:10.1111/ele.12144

627 R Development Core Team (2017) R: A Language and Environment for Statistical Computing. R Foundation 628 for Statistical Computing, Vienna, Austria.

629 Randin CF, Engler, R, Normand S, Zappa M, Zimmermann NE, Pearman PB, Vittoz P, Thuiller W, Guisan A 630 (2009) Climate change and plant distribution: local models predict high-elevation persistence. Glob $631 \quad$ Change Biol 15:1557-1569

632 Rangel TF, Diniz-filho JAF, Bini LM(2009) SAM : a comprehensive application for Spatial Analysis in 633 Macroecology. Ecography 33:46-50. doi:10.1111/j.1600-0587.2009.06299.x

634 Rangel TF, Loyola RD (2012) Labeling ecological niche models Nat Conserv 10:119-126

635 doi:10.4322/natcon.2012.030

636 Raup DM, Sepkoski JJ (1982) Mass extinctions in the marine fossil record. Science 215: 1501-1503 
637

638

639

640

641

642

643

644

645

646

647

648

649

650

651

652

653

654

655

656

657

658

659

660

661

662

663

664

665

666

Ribeiro LF, Alves ACR, Haddad CFB, Reis SF (2005) Two new species of Brachycephalus Günther, 1858 from the state of Paraná Southern Brazil. Bol Mus Nac Nov Ser Zool 519:10-18

Ribeiro LF, Bornschein MR, Belmonte-Lopes R, Firkowski CR, Morato SAA, Pie MR (2015) Seven new microendemic species of Brachycephalus (Anura: Brachycephalidae) from southern Brazil. PeerJ 3:e1011https://doi.org/10.7717/peerj.1011

Ribeiro MC, Metzger JP, Martensen AC, Ponzoni FJ, Hirota MM (2009) The Brazilian Atlantic Forest: How much is left, and how is the remaining forest distributed? Implications for conservation. Biol Cons 142:1141-1153

Ribeiro PL, Camacho A, Navas CA (2012) Considerations for assessing maximum critical temperatures in small ectothermic animals: Insights from leaf-cutting ants. PLoS One 7: e32083. doi:10.1371/journal.pone.0032083

Ricklefs RE, Schluter D (1993) Species diversity in ecological communities: historical and geographical perspectives. Chicago: University of Chicago Press.

Rodrigues ASL, Gaston KJ (2002) Maximising phylogenetic diversity in the selection of networks of conservation areas. Biol Cons 105:103-111

Safi K, Cianciaruso MV, Loyola RD, Brito D, Armour-Marshall K, Diniz-Filho JAF (2011) Understanding global patterns of mammalian functional and phylogenetic diversity. Phil Trans R Soc Ser B 366: 25362544 doi:10.1098/rstb.2011.0024)10.1098/rstb.2011.0024

Sinervo B, Méndez-de-la-Cruz F, Miles DB, Heulin B, Bastiaans E, Villagrán-Santa C, Lara-Resendiz R, Martínez-Méndez N, Calderón-Espinosa ML, Meza-Lázaro RN, Gadsden H, Avila LJ, Morando M, De la Riva IJ, Sepulveda PV, Rocha CFD, Ibargüengoytía N, Puntriano CA, Massot M, Lepetz V, Oksanen TA, Chapple DG, Bauer AM, Branch WR, Clobert J, Sites JW (2010) Erosion of lizard diversity by climate change and altered thermal niches. Science 328: 894-899 doi:10.1126/science. 1184695

Sobral FL, Cianciaruso MV (2012) Estrutura filogenética e funcional de assembleias: (re)montando a Ecologia de Comunidades em diferentes escalas espaciais. Biosc J 28:617-631

Soberón J (2007) Grinnellian and Eltonian niches and geographic distributions of species. Ecol Lett 10:11151123 doi:10.1111/j.1461-0248.2007.01107.x

SOS Mata Atlântica, INPE (2015) Atlas dos Remanescentes Florestais da Mata Atlântica Período 2013-2014. https://www.sosma.org.br/projeto/atlas-da-mata-atlantica/dados-mais-recentes/ 
667

668

669

670

671

672

673

674

675

676

677

678

679

680

681

682

683

684

685

686

687

688

689

690

691

692

693

694

695

Stenseth NC, Mysterud A, Ottersen G, Hurrell JW, Chan K, Lima M (2002) Ecological effects of climate fluctuations. Science 297:1292-1297

Stockwell DRB, Noble IR (1992) Induction of sets of rules from animal distribution data: a robust and informative method of data analysis. Math Comp Sim 33:385-390

Swenson NG (2014) Functional and Phylogenetic Ecology in R. - Springer, New York, NY.

Tabarelli M, Pinto LP, Silva JMC, Hirota M, Bede L (2005) Challenges and opportunities for biodiversity conservation in the brazilian Atlantic Forest. Conserv Biol 19:695-700

Tilman D (2001) Functional diversity. In Encyclopedia of Biodiversity (S.A. Levin, ed.). Academic Press, San Diego, p. 109-120

Thomas CD, Cameron A, Green RE, Bakkenes M, Beaumont LJ, Collingham YC, Erasmus BFN, Siqueira MF, Grainger A, Hannah L, Hughes L, Huntley B, van Jaarsveld AS, Midgley GF, Miles L, Ortega-Huerta MA, Townsend PA, Phillips OL, Williams SE (2004) Extinction risk from climate change. Nature 427:145-148 doi:10.1038/nature02121

Thomson AM., Calvin KV, Smith SJ, Kyle GP, Volke A, Patel P, Delgado-Arias S, Bond-Lamberty B, Wise MA, Clarke LE, Edmonds JA (2011) RCP4. 5: a pathway for stabilization of radiative forcing by 2100. Climat Chang 109:77 https://doi.org/10.1007/s10584-011-0151-4

Thuiller W, Lavorel S, Araújo MB, Sykes MT, Prentice IC (2005) Climate change threats to plant diversity in Europe. Proc Nat Acad Sci 102:8245-8250 doi:10.1073/pnas.0409902102

Thuiller W, Lavergne S, Roquet C, Boulangeat I, Araújo MB (2011) Consequences of climate change on the Tree of Life in Europe. Nature 448:550-552

Trindade-Filho J, Carvalho RA, Brito D, Loyola RD (2012) How does the inclusion of Data Deficient species change conservation priorities for amphibians in the Atlantic Forest? Biodivers Conserv 21:2709-2718

Urban MC, Richardson JL, Freidenfelds NA (2014) Plasticity and genetic adaptation mediate amphibian and reptile responses to climate change. Evol Appl 7: 88-103

Wake DB, Vredenburg VT (2008) Are we in the midst of the sixth mass extinction? A view from the world of amphibians. Proc Nat Aca Sci 105:11466-11473 doi: 10.1073/pnas.0801921105.

Webb CO, Ackerly DD, Mcpeek MA, Donoghue MJ (2002) Phylogenies and community ecology. Ann Rev Ecol Syst 33: 475-505

Wells KD (2007) The ecology and behavior of amphibians. University of Chicago Press. 
696 Weiher E, Keddy PA (1999) Ecological Assembly Rules - Perspectives, advances, retreats. Cambridge:

697 Cambridge University Press.

698 Vaidya G, Lohman DJ, Meier R (2011) Sequence Matrix: concatenation software for the fast assembly of multi699 gene datasets with character set and codon information. Cladistics 27:171-180

700 Visser ME (2008) Keeping up with a warming world: assessing the rate of adaptation to climate change. Proc R

701 Soc Lond B 275: 649-659

702

703 
Table 1. Multiple linear regressions on altitude vs bioclimatic variables to present and future.

\begin{tabular}{lcccc}
\hline & Stimated Std. & Error & t value & $P$ \\
\cline { 2 - 5 } & Present/Future & Present/Future & Present/Future & Present/Future \\
\hline $\begin{array}{lcccc}\text { (Intercept) } \\
\text { Annual Mean }\end{array}$ & $3821.527 / 4566.084$ & $85.25597 / 82.31261$ & $44.82 / 55.47$ & $<0.001$ \\
$\begin{array}{l}\text { Temperature } \\
\text { Temperature }\end{array}$ & $-152.191 /-168.309$ & $2.35075 / 2.33988$ & $-64.74 /-71.93$ & $<0.001$ \\
$\begin{array}{l}\text { Annual Range } \\
\begin{array}{l}\text { Precipitation of } \\
\text { Wettest Month }\end{array}\end{array}$ & $-16.7108 /-7.51973$ & $0.90175 / 0.72161$ & $-18.53 /-10.42$ & $<0.001$ \\
$\begin{array}{l}\text { Precipitation of } \\
\begin{array}{l}\text { Driest Month } \\
\text { Precipitation of }\end{array}\end{array}$ & $-7.93307 /-12.0148$ & $0.28229 / 0.22446$ & $-28.10 /-53.53$ & $<0.001$ \\
$\begin{array}{l}\text { Warmest Quarter } \\
\text { R-squared }\end{array}$ & $-0.42978 /-0.51133$ & $0.03805 / 0.03226$ & $-11.29 /-15.85$ & $<0.001$ \\
F-statistic & & $0.60 / 0.59$ & & $<0.001$ \\
\hline
\end{tabular}

706 


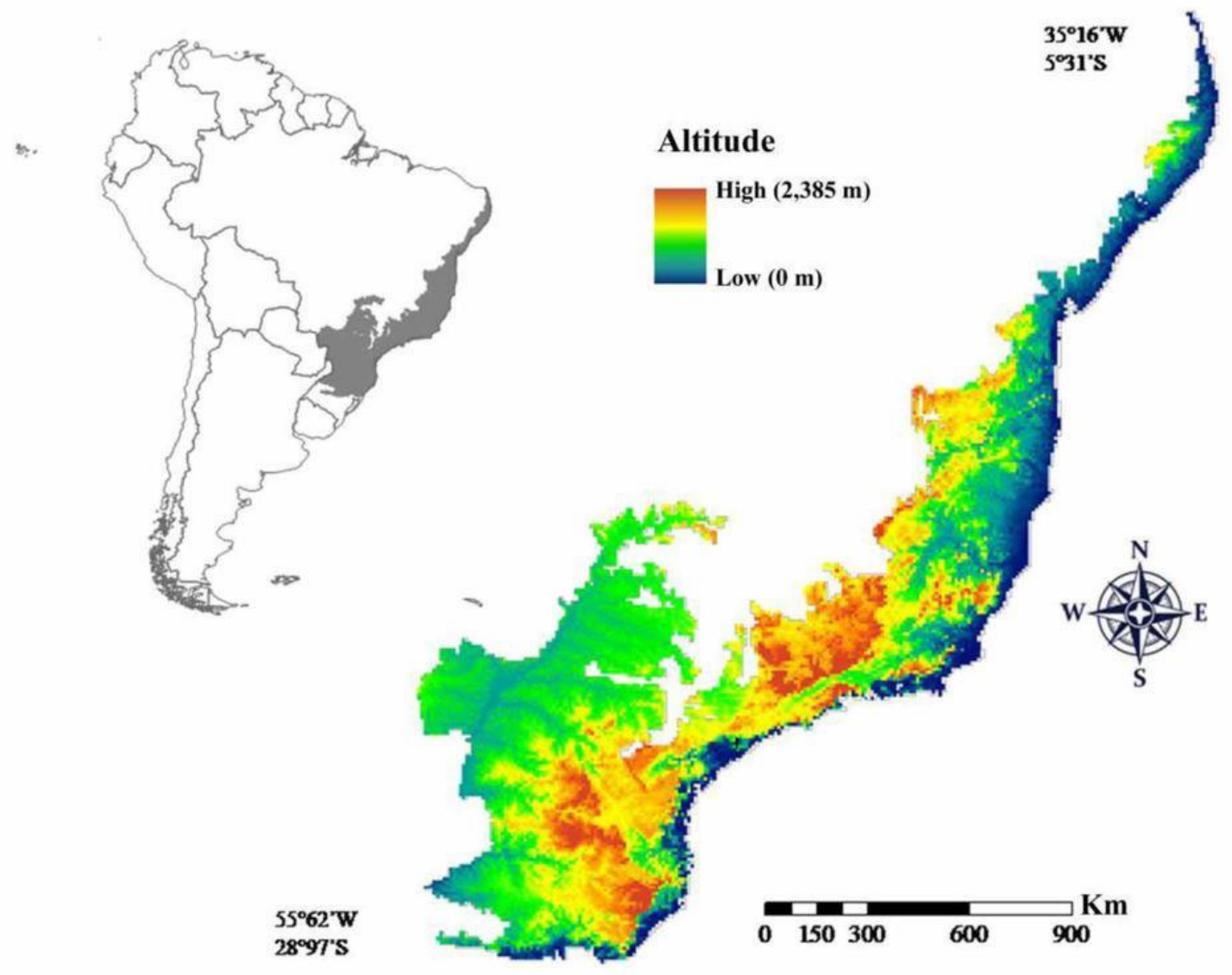

708

709

Fig. 1. Map of the study area of Brazilian Atlantic Forest hotspot. 

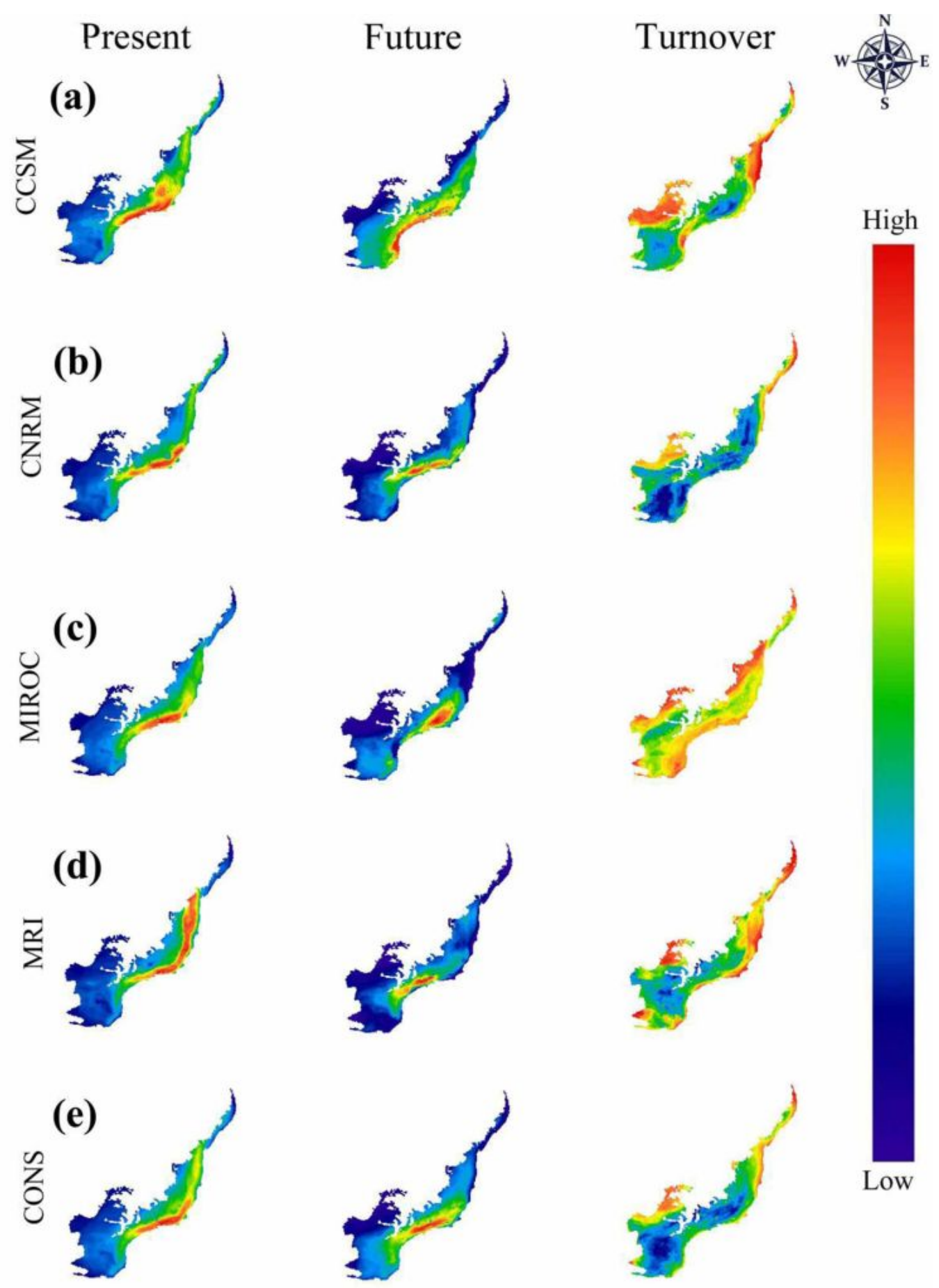

Fig. 2. Species richness and turnover derived from different Global Circulation Models (a) CCSM, CNRM (b),

713 MIROC (c), MRI (d) and Richness Consensual Model-CONS (e) for amphibian species in the present time and for 2080. 


\section{(a) CONS present}

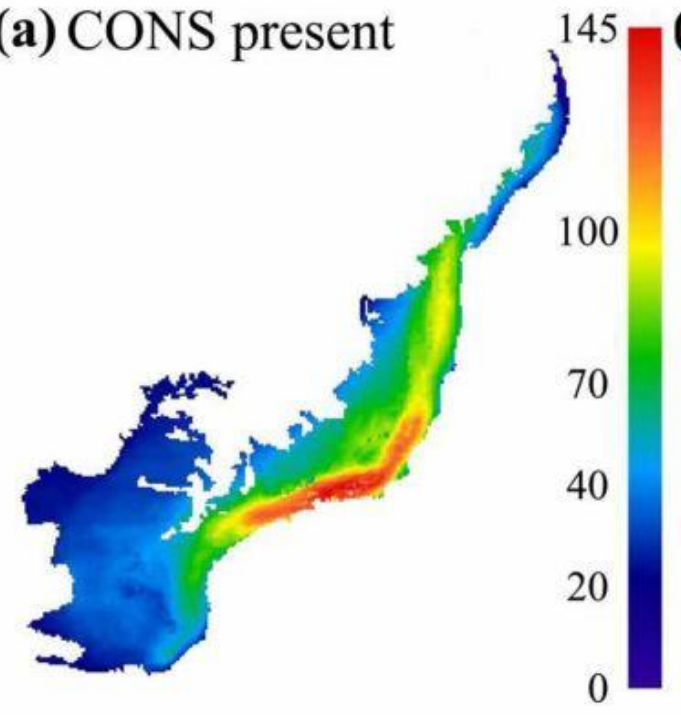

(c)

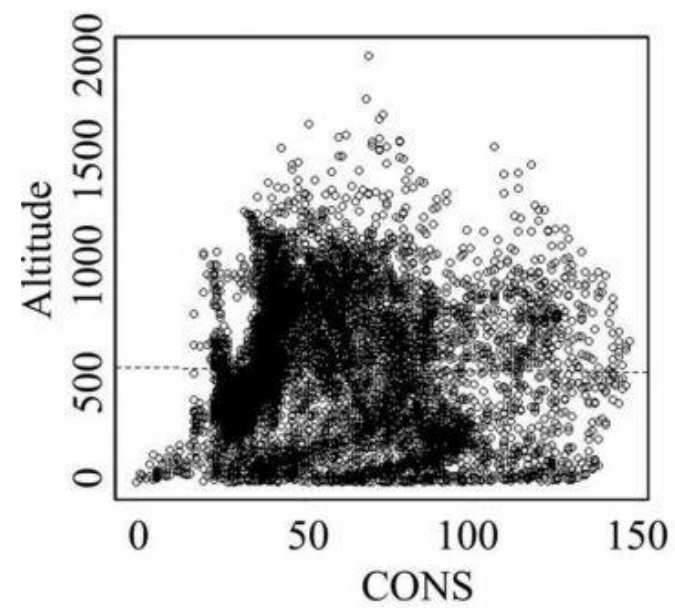

(b) CONS future

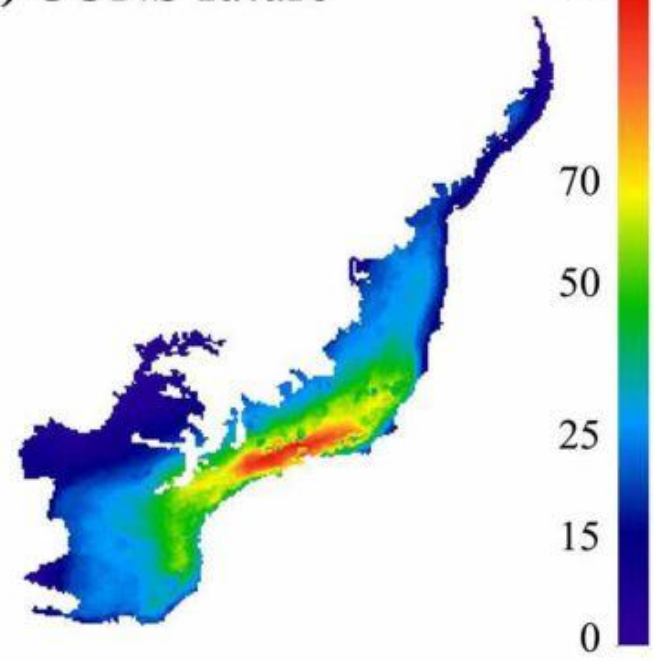

716

(d)

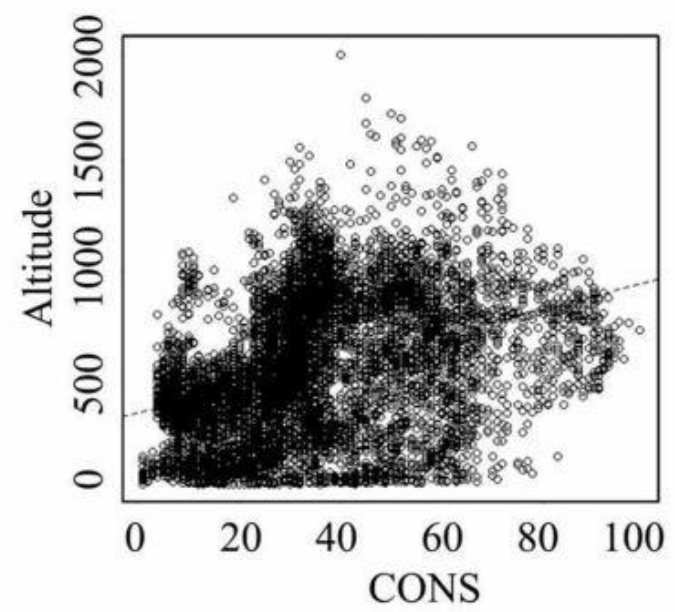

717 Fig. 3. Species richness derived from consensus model map for present time (a) and for 2080 (b). Relation

718 between amphibian species richness consensual model (CONS) and altitude (in meters) for present time (c) and

719 for 2080 (d). 


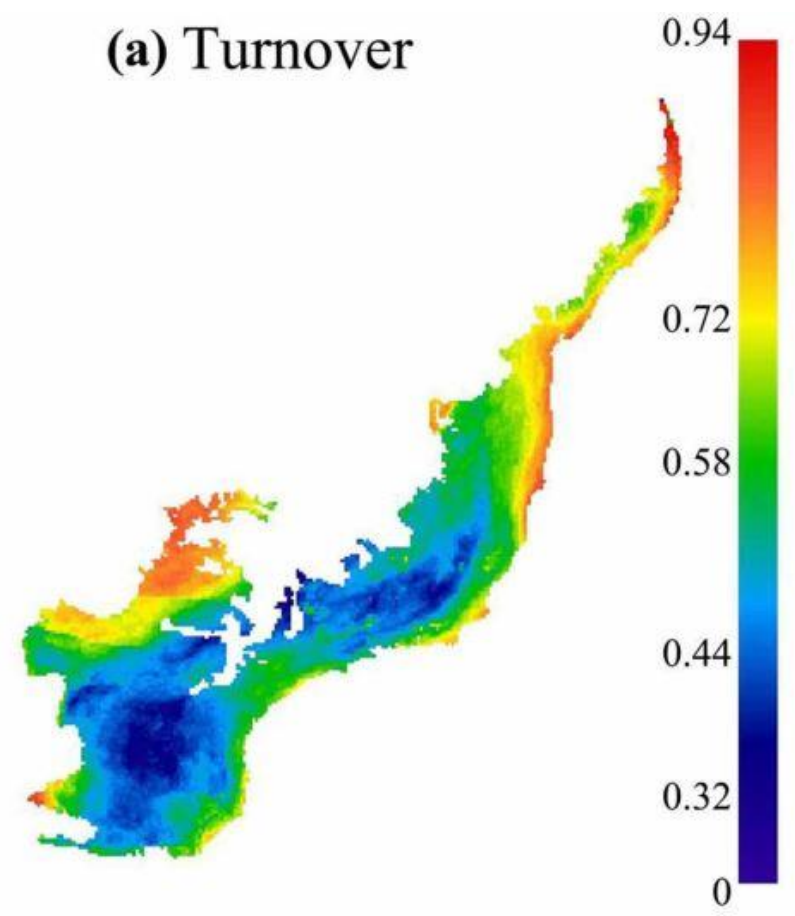

(b)

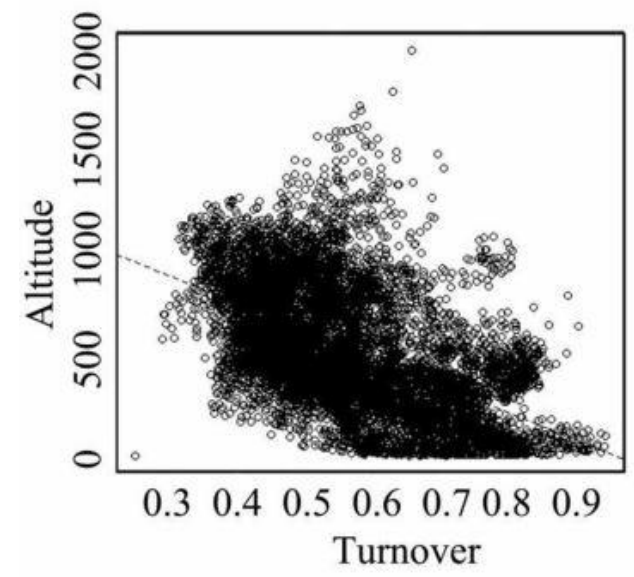

(c)

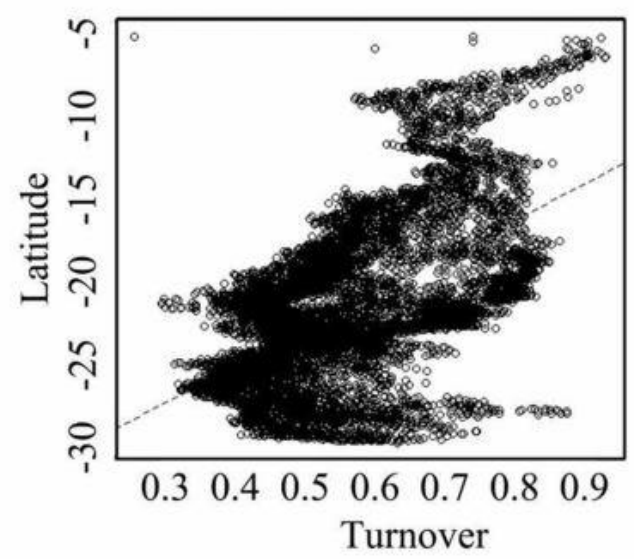

722 Fig. 4. Turnover derived from consensus model map (a). Relation between turnover consensus model with

723 altitude (in meters) (b), and latitude (c) for amphibian species. 

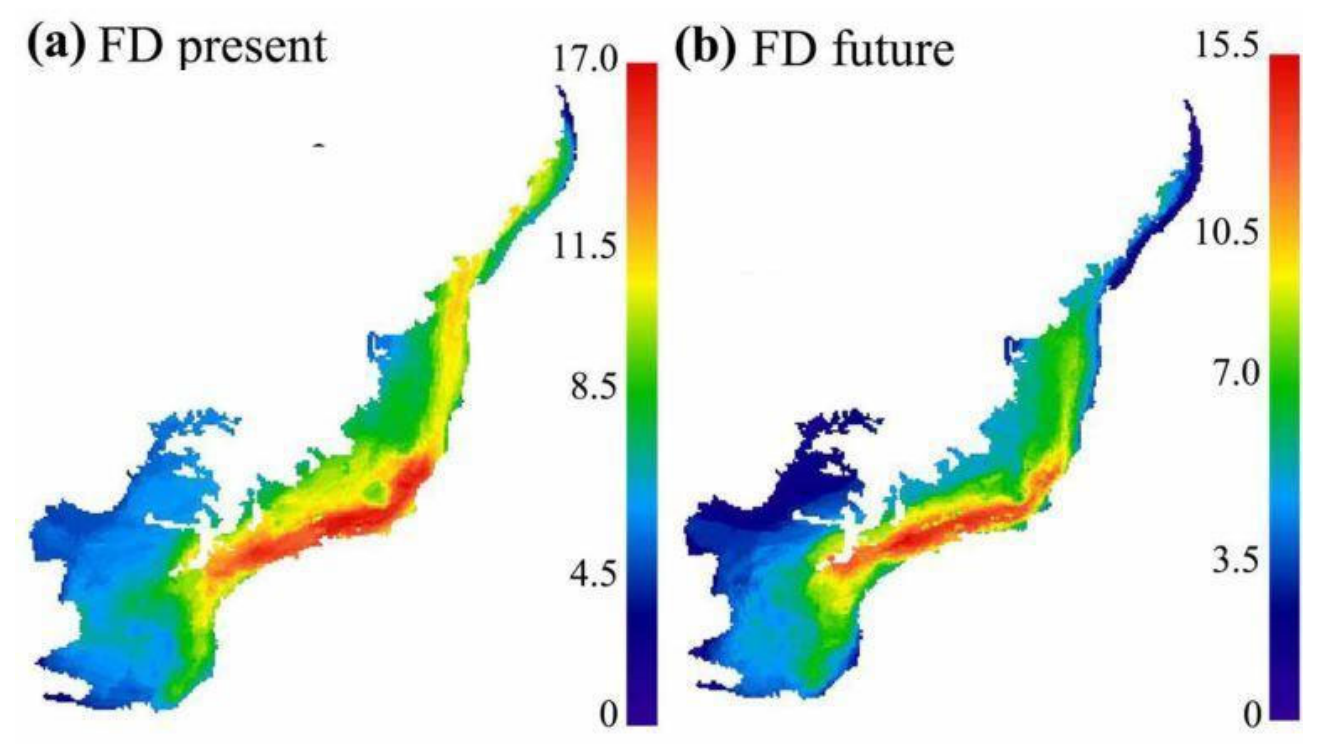

\section{(c)}

\section{(d)}
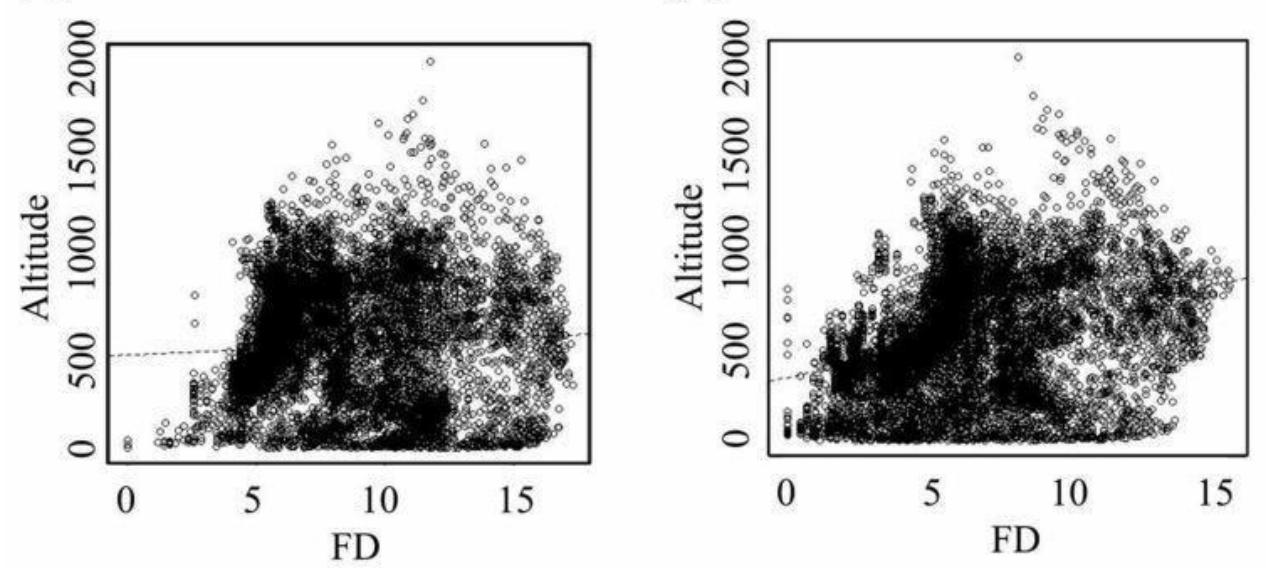

725

726 Fig. 5. Spatial distribution of Functional diversity (FD) derived from amphibian species richness consensus

727 model map for present time (a) and for 2080 (b). Relation between Functional diversity (FD) consensus model

728 and altitude (in meters) for present time (c) and for 2080 (d). 


\section{(a) PD present}

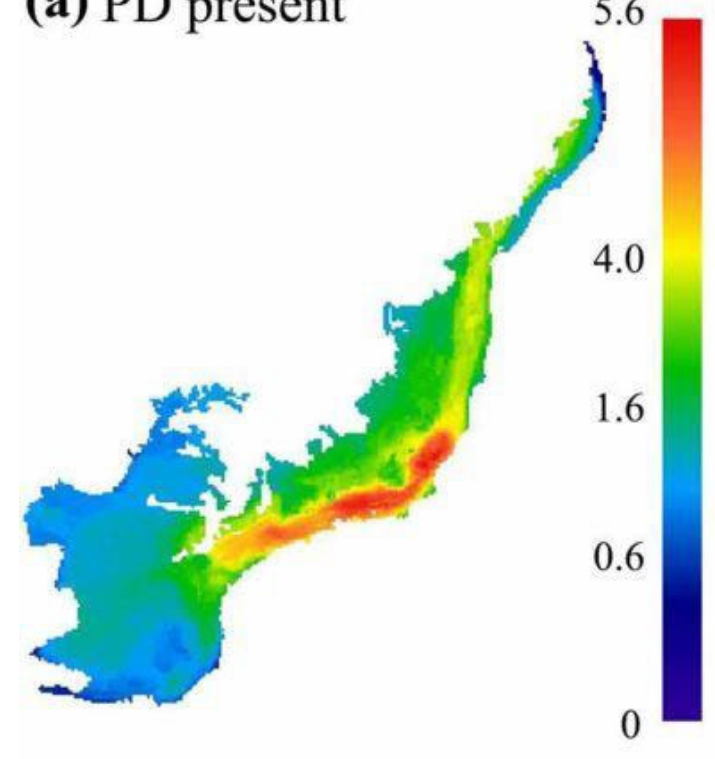

(c)

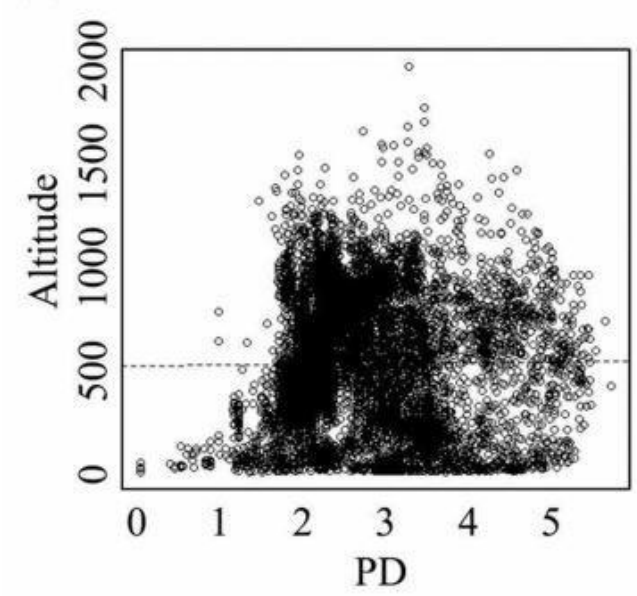

(b) PD future

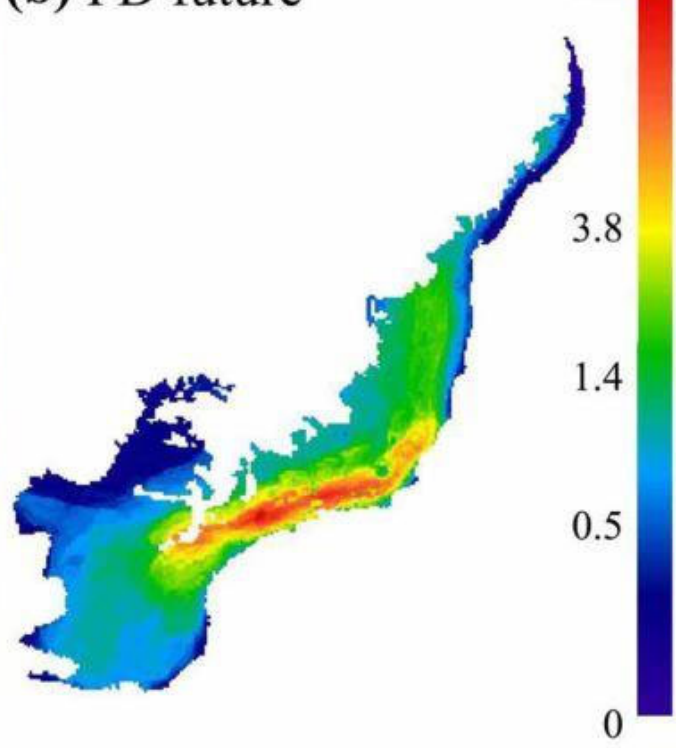

(d)

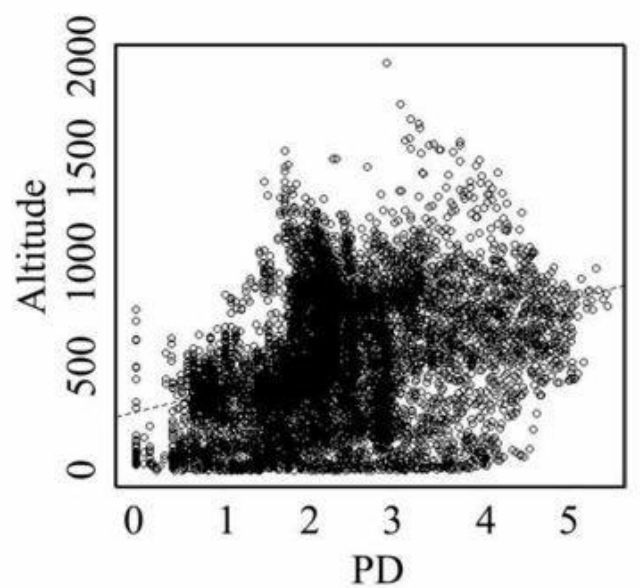

730

Fig. 6. Spatial distribution of Phylogenetic diversity (PD) derived from amphibian species richness consensus model map for present time (a) and for 2080 (b). Relation between Phylogenetic diversity (PD) consensus model and altitude (in meters) for present time (c) and for 2080 (d).

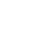


Present

\section{(a)}

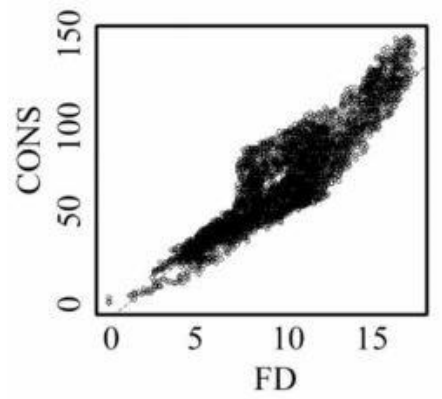

(d)

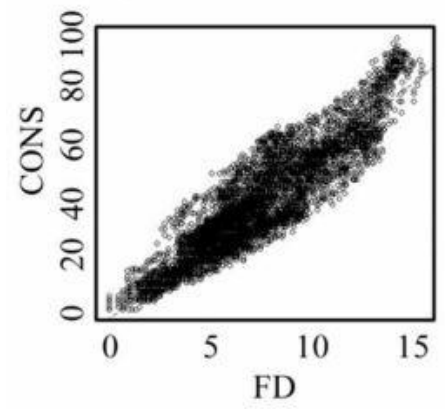

(b)

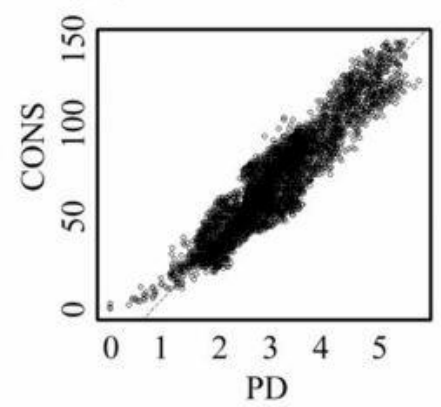

Future

(e)

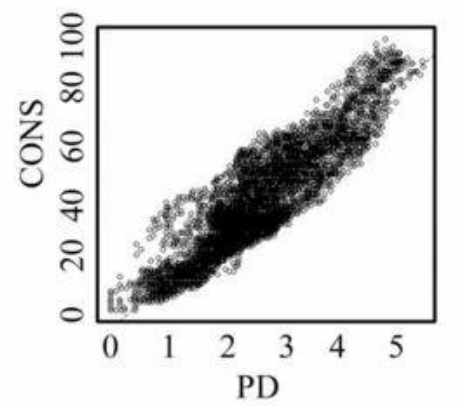

(c)

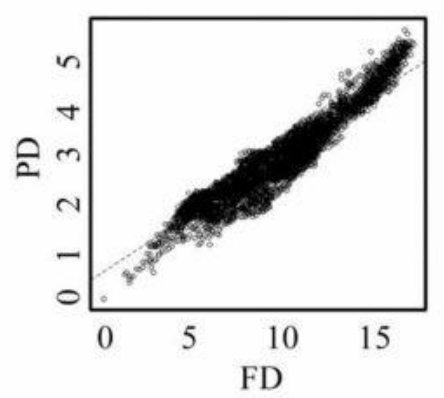

(f)

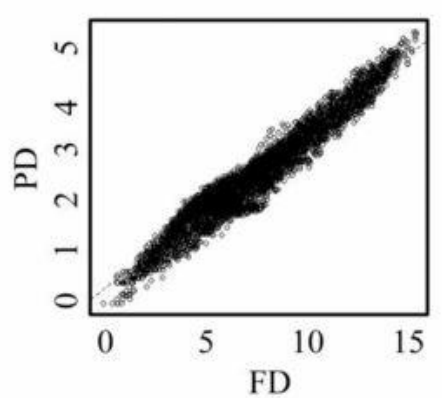

736

737 Fig. 7. Relationships between species richness consensual model (CONS), Functional diversity (FD),

738 Phylogenetic diversity (PD) of amphibians in the Brazilian Atlantic Forest. Present time: CONS vs FD (a),

739 CONS vs PD (b) and FD vs. PD (c); Future time: CONS vs FD (d), CONS vs PD (e) and FD vs PD (f). 
(a)

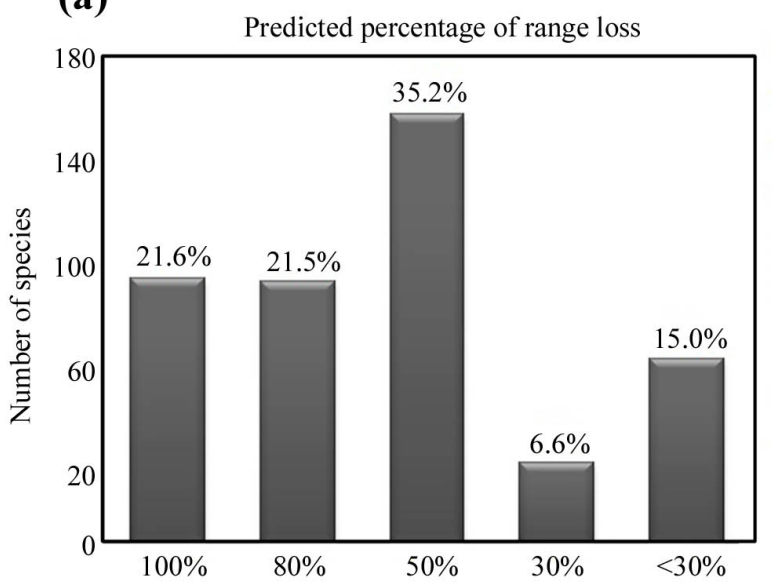

(b)

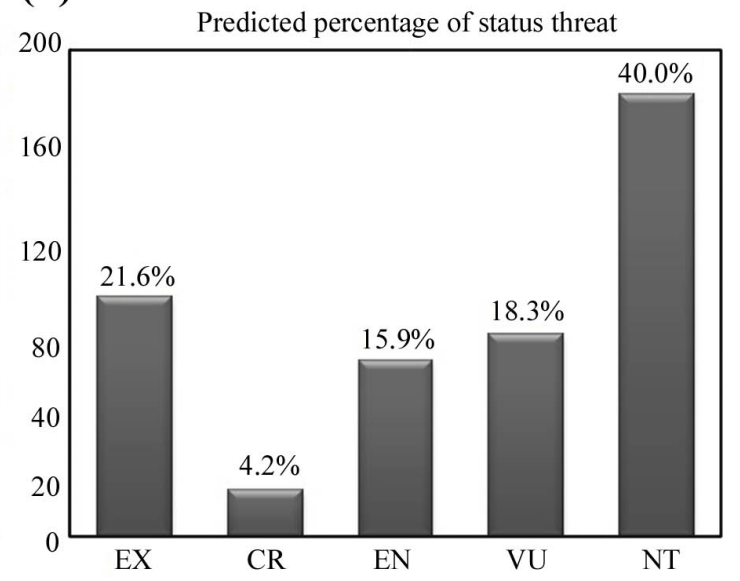

743

744 Fig. 8. Status of threat projection to 2080 in the face of climate change for amphibians of Atlantic Forest hotspot.

745 In the top of bars is the percentage of species number. (a) percentage of lost species range; (b) status of species:

746 Extinct (EX) $0 \mathrm{~km}^{2}$, Critically Endangered (CR) $<100 \mathrm{~km}^{2}$, Endangered (EN) $<5,000 \mathrm{~km}^{2}$, Vulnerable (VU) $<$

$74720,000 \mathrm{~km}^{2}$, and Nonthreatened (NT) $>20,000 \mathrm{~km}^{2}$. 


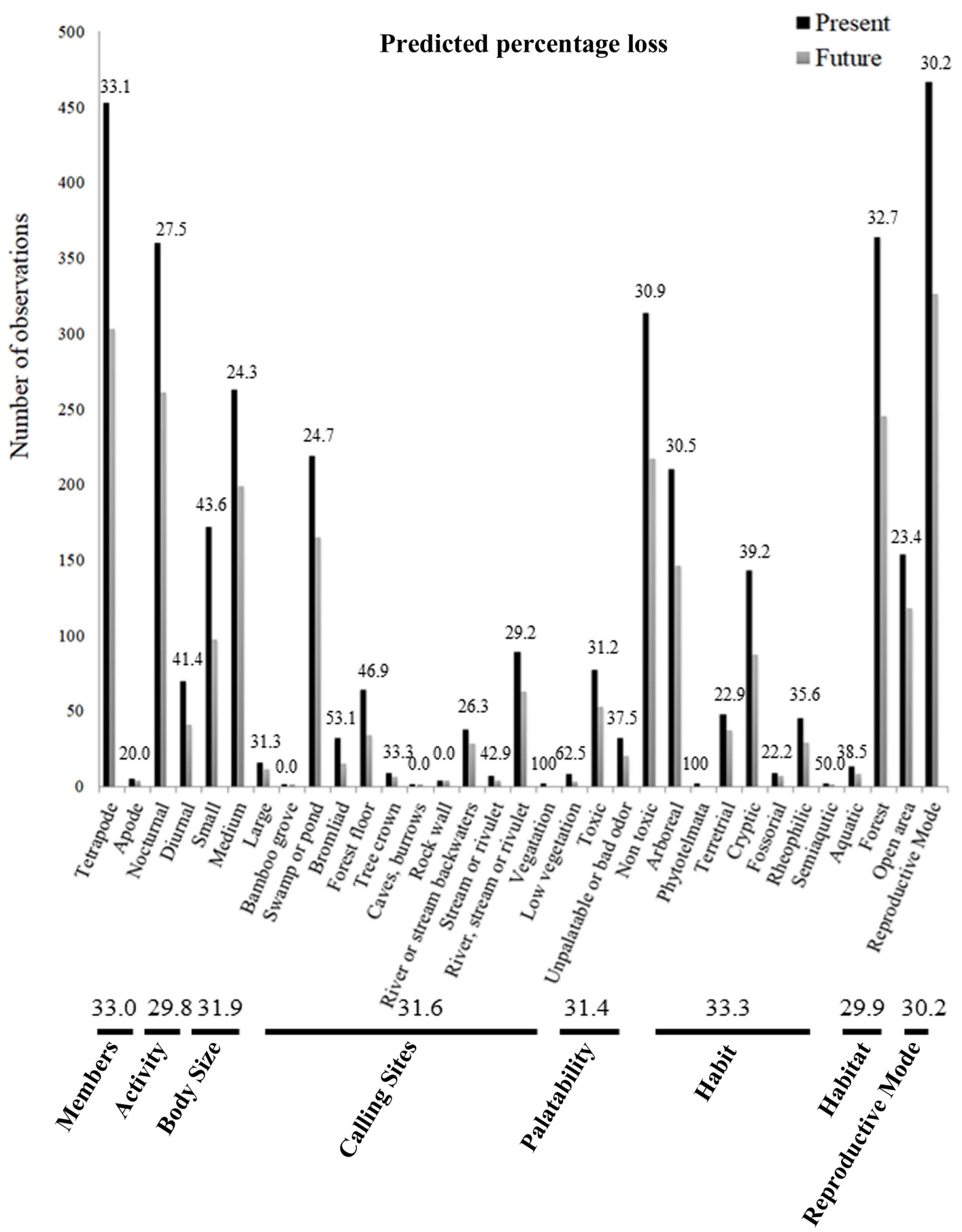

750 Fig. 9. Predicted percentage loss of functional traits and subtraits to 2080 in the face of climate change for 751 amphibians of Atlantic Forest hotspot. 